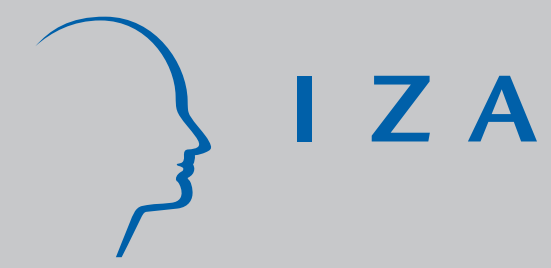

IZA DP No. 54

Labor Market Assimilation and the SelfEmployment Decision of Immigrant Entrepreneurs

Magnus Lofstrom

August 1999 


\title{
Labor Market Assimilation and the Self-Employment Decision of Immigrant Entrepreneurs
}

\author{
Magnus Lofstrom \\ IZA, Bonn \\ Discussion Paper No. 54 \\ August 1999 \\ IZA \\ P.O. Box 7240 \\ D-53072 Bonn \\ Germany \\ Tel.: +49-228-3894-0 \\ Fax: +49-228-3894-210 \\ Email: iza@iza.org
}

This Discussion Paper is issued within the framework of IZA's research area Mobility and Flexibility of Labor Markets. Any opinions expressed here are those of the author(s) and not those of the institute. Research disseminated by IZA may include views on policy, but the institute itself takes no institutional policy positions.

The Institute for the Study of Labor (IZA) in Bonn is a local and virtual international research center and a place of communication between science, politics and business. IZA is an independent, nonprofit limited liability company (Gesellschaft mit beschränkter Haftung) supported by the Deutsche Post AG. The center is associated with the University of Bonn and offers a stimulating research environment through its research networks, research support, and visitors and doctoral programs. IZA engages in (i) original and internationally competitive research in all fields of labor economics, (ii) development of policy concepts, and (iii) dissemination of research results and concepts to the interested public. The current research program deals with (1) mobility and flexibility of labor markets, (2) internationalization of labor markets and European integration, (3) the welfare state and labor markets, (4) labor markets in transition, (5) the future of work, and (6) general labor economics.

IZA Discussion Papers often represent preliminary work and are circulated to encourage discussion. Citation of such a paper should account for its provisional character. 


\section{ABSTRACT}

\section{Labor Market Assimilation and the Self-Employment Decision_of Immigrant Entrepreneurs}

This paper uses data from the 1980 and 1990 U.S. Censuses to study labor market assimilation of self-employed immigrants. Separate earnings functions for the self-employed and wage/salary workers are estimated. To control for endogenous sorting into the sectors, models of the self-employment decision are estimated. Variables for the proportion of immigrants in the population and average earnings ratios are used as instruments to control for self-selection into self-employment and consequently identify the inverse Mills correction term in the earnings models. Self-employed immigrants do substantially better in the labor market than wage/salary immigrants. Earnings of self-employed immigrants are predicted to converge with natives' wage/salary earnings at about age 30 and natives' self-employed earnings at about age 40. Including the self-employed in the sample reduces the immigrantnative earnings gap by, on average, roughly 14 percent.

JEL Classification: J15, J23, J61

Keywords: Immigration, assimilation, self-employment

Magnus Lofstrom

IZA

P.O. Box 7240

D-53072 Bonn

Germany

Tel.: +492283894303

Fax: +492283894210

email: lofstrom@iza.org

\footnotetext{
* I am very thankful to Julian Betts for numerous insightful comments on several revisions of this paper. I am also grateful to Steve Raphael, James Rauch, David Riker and Akos Rona-Tas for helpful comments.
} 


\section{Introduction}

One of the "stylized facts" in the economics of immigration is that immigrants arriving in the U.S. in the last decades are not performing as well in the labor market as their counterparts who arrived in the 1940's and 1950's (Borjas, 1985 and 1995). Notably, self-employed immigrants have continuously been excluded from studies finding a decline in quality of immigrants. This paper takes a closer look at the performance and assimilation in the labor market of self-employed immigrants. The paper explores two aspects of self-employment among immigrants. The first is the self-employment decision. More specifically, what are the main factors that cause the self-employment rates to differ between immigrants and natives, and what are the roles of these factors? The other aspect explored in the paper is labor market assimilation of self-employed immigrants. I ask whether the decline in immigrant quality holds equally in the self-employed sector and whether self-employed immigrants assimilate into the labor market, in terms of earnings, at the same rate as wage/salary workers. Also, at what point, if at all, do immigrants' earnings reach parity with self-employed native born Americans? The consequence of excluding the self-employed on the immigrant-native wage gap is also analyzed.

The lack of attention to the self-employed sector could easily be justified if either it was represented by a relatively small proportion of the labor force or if selfemployed individuals possess very similar socioeconomic characteristics to wage and salary workers (i.e. they are simply a random sub-sample of the labor force). Neither of these statements is in fact true. Using the 1980 and 1990 Census of Population, I 
find that 10.39 percent of native born American males in the labor force were selfemployed in 1980 and this increased to 11.21 percent in 1990. The proportions for immigrant men in 1980 and 1990 were 11.63 percent and 12.20 percent respectively, but vary greatly over ethnic groups and arrival cohorts (see Table 1). This is certainly not a small number of workers given that the total male labor force consists of over 70 million individuals ${ }^{1}$.

As will be shown, self-employed immigrant workers are also, on average, older by about 5 to 6 years, display higher levels of English language fluency and are generally more educated than wage/salary immigrants. For example, in 1990 self-employed immigrants had on average to 1.5 years more schooling than immigrants in the wage/salary sector. Self-employed workers also have higher total annual earnings than wage/salary workers do 2 . However, earnings from self-employment may not only reflect returns to human capital, but also returns to physical capital. A better comparison between wage/salary workers and self-employed individuals may be income including total earnings and investment income. This too is higher for selfemployed persons. The fact that self-employed individuals are both more educated and older is likely to explain some of these differences.

It is also interesting to note that the ratio of earnings of self-employed workers to earnings of wage/salary employees varies substantially across immigrant groups. For

\footnotetext{
${ }^{1}$ Using the Current Population Survey, Bregger (1996) estimated that 6.7 million men were selfemployed in 1994.

${ }^{2}$ Total earnings in this paper is defined as the sum of annual earnings from wage/salary work and selfemployment earnings. The reason for this is that an individual may report earnings from both sectors. A person is defined to be self-employed if he reports to be self-employed in own incorporated or not incorporated business, professional practice or farm and who has no farm self-employment income, i.e.
} 
example, in the South East Asian national origin group the ratio in 1980 was 2.72 .

That is, self-employed individuals in this group had 172 percent higher earnings than their wage/salary co-nationals. At the other extreme is the European, Canadian, Australian and New Zealand group. The earnings ratio of the self-employed to wage/salary workers in 1990 for this national origin group indicates relatively little difference in earnings between the two sectors. The self-employed enjoy approximately 23 percent higher earnings than wage/salary workers in this national origin group.

Overall, both immigrants and natives who chose self-employment increased their earnings advantage over wage/salary workers in the last decade. In 1980 the selfemployment to wage/salary earnings ratio was 1.42 for natives and 1.57 for all immigrants. By 1990 it increased slightly to 1.43 for natives and to 1.62 for immigrants.

Self-employment is also commonly believed to be an important tool in immigrants' cultural and economical assimilation process. As such, it may be an important stepping stone towards upward social and economic mobility (Cummings, 1980).

In this paper I estimate separate earnings functions for the self-employed and wage/salary workers. To control for endogenous sorting into the sectors, models of the self-employment decision are estimated. Variables for immigrant population proportion and the ratio of average self-employment earnings to average wage/salary

self-employed farmers are excluded from the study. All other working individuals are defined as wage/salary workers. 
earnings ratios, by national origin group and SMSA, are used as instruments to identify the inverse Mills correction terms. The estimated earnings functions are used to generate sector specific measures of labor market assimilation. I find that wage/salary immigrants do not reach earnings parity with natives. However, earnings of self-employed immigrants appear to converge with and surpass earnings of both wage/salary and self-employed natives. Using the consistent estimators from the earnings equations, I develop a new economy wide measure of assimilation that accounts for the distribution across sectors. This shows that the immigrant-native earnings gap is overstated when the self-employed are excluded from the study.

The paper is organized in the following way. Section 2 describes the data used and how national origin groups were created. Section 3 outlines and compares traits of immigrants and natives in the two sectors. Implications of these characteristics on selfemployment rates and earnings are discussed. In Section 4, the self-employment decision model is described and Section 5 shows the empirical results. Earnings equations are presented in Section 6. Age-earnings profiles are derived and discussed in this section, as is the implication of excluding the self-employed. Finally, Section 7 summarizes the results of the study.

\section{Data and National Origin Group Definition}

The data used in this paper are drawn from the $19805 \%$ A Sample and the 1990 5\% Sample of the U.S. Census of Population. The study includes males between the ages of 18 and 64 who are not residing in group quarters, who are not in military 
service or enrolled in school, and who reported working in the year prior to the census ${ }^{3}$. Given the extremely large data set this leaves us with, I extracted a 20 percent randomly selected sub-sample of native born Americans from the 5\% Sample, but kept all immigrants.

It is interesting to note that the selection process that determines who migrates or not, and hence the labor market performance of immigrants, is believed to be determined by the relative conditions in host and source country (see for example Borjas, 1987). However, the majority of studies on immigrant performance have been done based on ethnic groups, and not on country of origin. In this paper I try to create 10 relatively homogenous groups based on countries' geographic location and cultural and economic conditions, while maintaining a large enough sample size for each group.

It should be noted that any attempt to create homogenous groups will be scarred by compromises. As noted above, there are substantial differences in characteristics such as self-employment rates and educational attainment between immigrant groups. If the group is defined too widely, the impact of variations in these variables may not be accurately estimated. If the group is too narrowly defined, by country for example, the sample size will be small for some of the countries. This is particularly true when studying self-employed immigrants, a group that represents approximately one percent of the male labor force ${ }^{7}$. However, if different ethnic groups face different labor

\footnotetext{
${ }^{3}$ Individuals who reported a weekly wage over \$20,000, in 1989 dollars, are excluded from the study. Also, individuals who reported a weekly wage of less than $\$ 50$ are ignored. Since the 1990 Census is not a random sampling of the population, sample weights are used for all calculations and estimations. ${ }^{4}$ The U.S. Immigration and Naturalization Service estimates that in 1990, 7.9 percent of the total U.S. population was foreign born. Given a self-employment rate of 12.2 percent for male immigrants, the
} 
market constraints, such as discrimination, creating groups based on national origin may not be the best way to compose groups. Table A1 in the appendix describes the countries represented in each national group used in this paper.

It can be seen in Table 6 that there are substantial differences between national origin groups in terms of educational attainment and English proficiency. However, the goal of creating the national origin groups is to obtain groups that are relatively homogenous within the group to reduce the observed heterogeneity among immigrants overall. To check whether there is more variation in traits, say education, across groups than within, a regression model was estimated using as the dependent variable years of education on the national origin dummies. The estimated coefficients on the national origin group variables can be used to test for differences between the groups. The model also includes variables for age, age interacted with immigrant status, years since migration and dummies for immigrant status, a period effect and arrival cohorts. The hypothesis tests of equality of national origin coefficients are rejected in all comparisons except one, between the North East Asian and the Middle Eastern group (results are not presented here). Furthermore, both the variance and the interquartile range of years of education are smaller for all national origin groups as compared to the variance or interquartile range for all immigrants. For example, in 1990 the interquartile range for all immigrants was 7 years while on average it was roughly 4.5 years for the national origin groups. The interpretation of these results is that variations in educational attainment are much greater between groups than within

proportion of self-employed immigrants of the total male population would be 0.96 percent, assuming men and women comprise an equal share of foreign born. 
groups. At least in terms of this human capital variable, the national origin groups are relatively homogenous.

The ethnic composition of a national origin group is also a measure of homogeneity of the group. Table A2 shows the ethnic composition of natives, all immigrants and immigrants broken into the national origin groups. The ethnic groups are defined as whites, blacks, Asians, Hispanics and others. As with educational attainment it appears that a substantial part of the variation is across groups and not within. The most heterogeneous group is the African group. Note that this is the smallest national origin group. By defining it any more specifically, precision in the estimates will be lost due to a small sample size. In seven of the other national origin groups, Mexico, South East Asia, North East Asia, India/Pakistan, Middle East, Europe/Can/Aus/NZ and Cuba, the largest ethnic group make up at least 90 percent of the group's total population in the U.S. In the other two groups, the Central and South American group and the Caribbean group, the two largest ethnic groups make up at least 85 percent of the group population. The national origin groups used in this paper seem to be relatively homogenous in terms of the ethnic composition and appear to be reasonably defined groups.

\section{Characteristics - The Self-Employed v. Wage/Salary Workers}

In this section I outline traits of immigrants and natives in the two sectors. This descriptive portrait suggests that immigrants are highly heterogeneous, that the way 
they self-select into the self-employment and wage/salary sectors is not random, and that the nature of this self-selection may have changed during the 1980's.

Self-employment rates vary greatly over both national origin groups and arrival cohort. These are presented in Table 1. It is shown in this table that the Mexican national origin group displays the lowest self-employment rates both in 1980 and 1990 of any group. The group with the highest self-employment rate in both census years is the Middle Eastern national origin group. Table 1 also shows that immigrant selfemployment probabilities increase with time spent in the U.S. The most recent arrival cohorts in both census years display the lowest self-employment rates while the most senior cohort exhibits the highest rate. The rate also increases for each cohort between 1980 and 1990. Some of these increases are likely due to the fact that the average age of a cohort increases over time.

As stated above, self-employed individuals have higher earnings than wage/salary workers. Table 2 presents mean earnings and a measure of earnings dispersion, the ratio of the $90^{\text {th }}$ earnings percentile to the $10^{\text {th }}$ earnings percentile, by arrival cohort; Table 3 shows these statistics by national origin groups. Earnings are shown in 1989 dollars and are adjusted for inflation by the annual Consumer Price Index. From the average earnings shown in tables 2 and 3, earnings differentials between groups were calculated. Self-employed immigrants earned on average 4.6 percent more than selfemployed natives did in 1980. This advantage had disappeared by 1990 when selfemployed natives earned approximately 1.5 percent more than immigrants. Wage/salary immigrants displayed an earnings disadvantage of 6 percent and 15.3 percent respectively in 1980 and 1990. 
It appears that earnings among both wage/salary and self-employed immigrants declined during the 1980's. The overall relative decline is slightly more pronounced among wage/salary immigrants. However, the decline relative to natives among the most recent arrival cohorts who chose self-employment is greater than the relative decline of the most recent cohorts of wage/salary workers. Some of the relative drop can possibly be explained by the observation that earnings increased by more for selfemployed natives in the last decade than it did for wage/salary natives. It also appears that self-employed immigrants increase their earnings more rapidly with time spent in the U.S. during the 1980's than the wage/salary immigrants. These patterns suggest that cohort labor market performance of immigrants who arrived in the last decade may have declined slightly more amongst the self-employed than the wage/salary workers, but that labor market assimilation is more rapid for the self-employed.

However, the apparent drop in relative earnings to natives does not hold for all national origin groups. In fact, four of the national origin groups, North East Asia, India/Pakistan, Middle East/Egypt and Europe/Can/Aus/NZ, either increased their relative earnings advantage, compared to natives, or closed the gap entirely. This is true for both the self-employed individuals and wage/salary workers in these four national origin groups.

The distribution of earnings is also of interest when comparing the self-employed and wage/salary workers. The distribution of earnings can be seen as a measure of the returns to skill. If earnings in a sector are more equally distributed, it is less likely that the most skilled individuals will choose that sector, holding mean earnings constant. 
The dispersion of earnings, as measured by the ratio of the earnings of the $90^{\text {th }}$ percentile to the $10^{\text {th }}$ percentile, shown in table 3 display substantial differences between the self-employed and wage/salary workers. This ratio is roughly twice as large for self-employed natives, (11.12), compared to wage/salary natives, (5.75), and slightly less than twice as large for self-employed immigrants, (11.53), compared to immigrant wage/salary workers, (6.42), in 1980. By 1990 the earnings dispersion had increased for all four of these groups.

It is quite likely that differences in human capital explain some of the earnings disparity over national origin groups and arrival cohorts. The differences in educational attainment and English ability are seen in Tables 4, 5 and 6. These tables show the average years of schooling ${ }^{5}$, high school drop out rates, college graduation rates and the percentage of immigrants in the group who report that they do not speak English well or not at all.

Self-employed immigrants display lower high school drop out rates and higher college graduation rates than immigrant wage/salary employees. This is shown in Table 4. The educational attainment gap between self-employed and wage/salary immigrants increased in the 1980's while during the same period the gap between selfemployed and wage/salary natives decreased. If immigrants' education is valued less by U.S. employer than natives' education, as is found in Betts and Lofstrom (1998), it

\footnotetext{
${ }^{5}$ The coding of educational attainment changed in the 1990 Census. The data from 1990 is recoded in the following fashion. No school completed, nursery school and kindergarten are coded as 0 years of education; first through fourth grade are recoded as 2.5 years; fifth through eighth grade as 6.5 years; ninth grade as 9 years; tenth grade as 10 years; eleventh or twelfth grade without a high school diploma as 11 years; high school graduate as 12 years; some college, no degree as 13 years; associate degree as 14 years; bachelor's degree as 16 years; master degree as 17 years and professional and doctorate degree as 20 years.
} 
is plausible that relatively highly educated immigrants are more likely to choose selfemployment compared to relatively highly educated natives. This is possibly one of the reasons why the educational gap between the self-employed and wage/salary employees is greater for immigrants than for natives.

The decline in earnings, relative to natives, of recently arrived immigrants is possibly due to a decline in educational attainment. Table 5 displays the human capital variables described above by arrival cohorts.

The most recent cohort of immigrants who chose self-employment appear to have higher high school drop out rates and a lower percentage of college graduates in 1990 compared to 1980 . Table 5 also shows that in 1990 recent wage/salary immigrants displayed lower educational attainment levels than did recent wage/salary immigrants in 1980. The decline relative to natives is quite notable since during the 1980's, educational attainment levels increased quite considerably for both self-employed and wage/salary natives.

The apparent decline in schooling levels of immigrants does not hold for all immigrant groups. In fact, there is quite a difference in changes of educational attainment in the 1980's over national origin groups. These statistics are presented in Table 6. In general, the groups who displayed an improvement of relative earnings over the decade also exhibited increases in educational attainment levels.

Educational attainment of immigrants overall appears to have declined relative to natives in the 1980 's. The decline seems to be slightly greater among wage/salary immigrants than among self-employed immigrants. Furthermore, the educational attainment gap is generally smaller for self-employed immigrants than it is for 
wage/salary immigrants and in fact, the percentage of college graduates is greater for immigrant entrepreneurs than for self-employed natives.

Another form of human capital that is likely to affect earnings and income of immigrants is the level of English ability. Respondents to both the 1980 and 1990 Census long form questionnaire rate themselves as to whether they only speak English, speak English very well, well, not well or not at all. Surprisingly, few studies have used this particular information from the Census in analyzing immigrant labor market assimilation ${ }^{6}$. In this paper I create a dummy variable for limited English ability ${ }^{\text {日 }}$. The means of this variable are presented in Tables 4 through 6.

Self-employed immigrants report speaking limited English to a lesser extent than wage/salary immigrants. This is true for all arrival cohorts and national origin groups except for North East Asians and Cubans in 1990.

The level of English proficiency of immigrants appears to have changed in the last decade. Overall, there appears to be a shift in the distribution of English proficiency levels of immigrants from higher ability to lower ability. This shift seems to be more pronounced for self-employed immigrants than for wage/salary immigrants and varies over national origin groups. The increase in the numbers of immigrants coming to the U.S. in the last decade may have made it easier to "get by" with limited English ability. The increase makes it more likely or easier for immigrants to settle in areas

\footnotetext{
${ }^{6}$ One possible reason for this is the correlation between education and English ability. In regressions that include both these variables, it is hard to determine the impact on earnings that is due to education and what is due to English ability.

${ }^{7}$ This variable is set equal to one if the respondent indicated that they did not speak English well or if they did not speak English at all.
} 
with higher proportion of co-nationals, or in so called enclaves. The role of enclaves will be analyzed in the self-employment decision models below.

\section{The Self-Employment Decision}

Individuals choose whether to participate in the wage/salary sector of the labor market or to become self-employed. The decision will depend on several factors that determine potential earnings in each sector. Assuming that individuals are risk neutral and maximize expected net earnings, a person will chose self-employment if the expected annual net earnings from self-employment, denoted $y_{i}^{\text {s-e }}$, is greater than the annualized market wage, represented here by $y_{\mathrm{i}}^{\mathrm{w} / \mathrm{s}}$. Earnings in each sector will depend on a vector of observable characteristics, $\mathrm{X}$ and unobserved characteristics $\varepsilon$. Expected earnings in the two sectors can be defined as:

$$
\begin{aligned}
& y_{i}^{w / s}=\mathrm{X}_{i} \beta^{w / s}+\varepsilon_{i}^{w / s} \\
& y_{i}^{s-e}=\mathrm{X}_{i} \beta^{s-e}+\varepsilon_{i}^{s-e}
\end{aligned}
$$

where $\varepsilon^{w / s}$ and $\varepsilon^{s-e}$ are jointly normally distributed with mean zero and variances $\sigma_{w / s}^{2}$ and $\sigma_{s-e}^{2}$. An individual chooses self-employment if:

$$
I_{i}^{*}=y_{i}^{s-e}-y_{i}^{w / s}>0
$$

Clearly the index function $I_{i}^{*}$ is unobservable since we do not observe the earnings for the option not chosen. In other words, we do not observe the wage/salary earnings a 
self-employed individual would earn if the wage/salary sector were chosen. However, from equations (1), (2) and (3) $I_{i}^{*}$ can be defined as:

$$
I_{i}^{*}=y_{i}^{s-e}-y_{i}^{w / s}=\mathrm{X}_{i} \beta^{s-e}-\mathrm{X}_{i} \beta^{w / s}+\left(\varepsilon_{i}^{s-e}-\varepsilon_{i}^{w / s}\right)=W_{i} \pi+e_{i}
$$

If we set $I=1$ if $I_{i}^{*}>0$, if self-employment is chosen, and $I=0$ if $I_{i}^{*} \leq 0$, if the wage/salary sector is selected, then equation (4) can be seen as a probit model of sectoral choice of self-employment. It is well known that the parameters $\hat{\pi}$ and $\hat{\sigma}_{e}$ cannot be identified from estimation of equation (4). The estimate obtained is $\operatorname{instead}\left(\frac{\hat{\pi}}{\sigma_{e}}\right)$.

Estimating the self-employment decision in equation (4) has two main benefits. The first is that it will give us insight to the role of the different characteristics in choosing a sector. The question that can be answered through this process is: What are the reasons for the differences in self-employment rates between immigrants and natives and what are the roles of the factors? The second advantage is that from the probit estimates, the inverse Mills ratio can be calculated. This will help to correct for self-selection problems in the earnings functions through use of the Heckman two-step procedure.

\section{Empirical Model and Findings: The Self-Employment Decision}

The sectoral choice an individual makes will depend on several factors. As explained above, an individual is assumed to compare the earnings he expects to earn 
in the wage/salary sector, i.e. the market wage, to the expected net earnings from selfemployment. If this difference is positive, the individual chooses to be self-employed. The model to be estimated by probit is:

$$
I_{i}^{*}=W_{i} \pi+e, \text { where } e \sim \mathrm{N}(0,1)
$$

The probability an individual chooses self-employment is:

$\operatorname{Prob}\left[I_{i}=1\right]=\Phi(W \pi)$, where $\Phi(\cdot)$ is the standard normal cumulative density

function. The probability a person chooses the wage/salary sector is then simply:

$$
\operatorname{Prob}\left[I_{i}=0\right]=1-\Phi(W \pi)
$$

The interpretation of the estimated coefficients for the probit model is not as straightforward as the interpretation of coefficients from linear estimation methods. The sign of the coefficient indicate the direction of the marginal effect, but the size of the effect cannot be determined solely by the coefficient. Instead, the marginal effect of a one unit change in variable $w_{i k}$ on the probability of self-employment for person i in these models is:

$$
\frac{\partial P_{i}}{\partial w_{i k}}=\phi(W \pi) \pi_{k}
$$

In order to calculate the marginal effects, it is necessary to choose values for the variables in $W$. All variables that are not interacted with the immigrant dummy variable are assigned a value equal to the population mean. The variables age interacted with immigrant status, years since migration and years of schooling interacted with immigrant status are set equal to the mean value for immigrants only. All other indicator variables, i.e. cohort and national origin dummies, are set equal to 
zero unless otherwise noted. This way, indicator variables can be "turned on and off" to analyze impact of specific traits and situations for a particular cohort or nation origin group. The values of other variables, i.e. group characteristics, will be defined as they are introduced into the analysis.

The choice over self-employment will likely depend on socio-economic characteristics such as age, education, marital status and geographic location. If there are differences in the impact any of these variables have on earnings, we would expect these variables to affect the self-employment decision. For immigrants, it is likely that the number of years in the U.S. will also have an effect on this decision. Furthermore, both age and education may impact earnings and self-employment probabilities differently for immigrants compared to natives. This too needs to be incorporated in the model. All these individual characteristics and a period effect for 1980 are included in the matrix $W$. The probit estimation results for the above described model are presented in Table 7 as model 1. As expected, age and education are positively related to the probability of self-employment, as is years since migration for immigrants. It also appears that after controlling for years since migration, there is very little difference in self-employment probabilities between arrival cohorts. Also, immigrants are more likely to choose self-employment than natives even after the above described characteristics are controlled for.

Light (1984) argues that differences in traditions of commerce among immigrants from different countries help explain differences in self-employment rates among immigrants in the U.S. This may be one of the reasons for variations in selfemployment rates over countries of origin that is not captured by the observable traits 
in the model. To attempt to incorporate these country specific unobservables, Model 2 in Table 7 adds dummy variables for the national origin groups. The African national origin group is the reference group. Adding these variables has a considerable impact on the arrival cohort and immigrant coefficients. Model 1 predicts that an immigrant who arrived between 1965 and 1969 is approximately 0.7 percent less likely, but statistically insignificantly so, to be self-employed than an immigrant who arrived in the most recent cohort in 1990. The same individual, but now defined specifically to be from South East Asia, is according to Model 2 around 3 percent significantly less likely to choose self-employment than a co-national who arrived between 1985 and 1989. Identical changes arise for the other national origin groups and arrival cohorts. By simply including a dummy variable for immigrants and not controlling for country of origin, differences in self-employment probabilities are greatly understated.

The impact of number years of education on the self-employment decision is also inaccurately estimated if no country of origin variables are included. Using the immigrant characteristics above, Model 1 predicts a positive marginal effect of slightly more than 7 percent on the probability of self-employment for an additional year of schooling. However, the estimates in Model 2 suggest that the marginal increase is only about 2.5 percent. The substantial change in probabilities from adding national origin variables may be related to both differences in levels and quality of education across countries. Nonetheless, it is quite clear that it is important to control for country of origin in the sectoral choice models of self-employment. The role of education in the self-employment decision is also very different for immigrants compared to natives. The marginal impact of education for a native with same 
characteristics as the immigrant described above is close to 7 percent. Education appears to play a greater role in choosing sector for natives than it does for immigrants.

One of the reasons for estimating the probits of the self-employment decision is to calculate the inverse Mills ratio. The objective in doing so is to reduce the possible selection bias that may arise in the estimated wage models. The goal is to include in the probit model variables that will influence the self-employment decision, but that will not affect earnings. It is highly desirable, but not necessary, for the probit model to include instruments that help to predict self-employment but which do not belong directly in the earnings function. I now discuss these additional instruments.

The first instrument added to Model 2 is a variable to test whether immigrants living in areas where relatively many co-nationals reside, so called enclaves, may be the reason we observe higher self-employment rates for some immigrant groups. The sociology literature commonly speaks of ethnic resources as a determinant in an individual's choice of whether or not to choose self-employment (see for example Light, 1984 and Aldrich and Waldinger, 1990). Examples of ethnic resources are skills or knowledge to provide services or goods to other co-ethnics or co-nationals, availability of low wage labor, social support networks that assist an individual in obtaining necessary start-up capital or in transferring managerial skills. Aldrich and Waldinger (1990) describe "opportunity structures" as market conditions that may favor goods or services oriented towards co-ethnics or co-nationals. Immigrants who are living in areas with relatively high proportions of co-nationals may have a comparative advantage in providing certain goods or services, food or restaurant 
services for example, to their co-nationals compared to natives or other immigrants.

The result, according to this theory, is higher self-employment rates among immigrants living in enclaves.

Hence, Model 3 extends Model 2 by adding a variable for the proportion of immigrants in the census year of the total population by SMSA and country of origin. This is calculated by adding up the number of male immigrants in the sample from a particular country in the SMSA and then dividing this by the total male population in the sample in the SMSA. For immigrants living in a non-SMSA area, the proportion is calculated based on the state's non-SMSA immigrant population. Given the definition above, it follows that the value of this variable is zero for all natives. The coefficient of this variable is positive and highly significant. This indicates that immigrants living in an area where a greater proportion of co-nationals are living, increases the probability of self-employment. For example, for a Mexican immigrant living in a SMSA where 10 percent of the population also come from Mexico, the mean value for Mexican immigrants, an increase in the proportion of Mexicans by 1 percent in the area increases the probability of self-employment by 0.1 percent. The proportion of co-nationals in the area appears to greatly influence the self-employment decision of Cuban immigrants. Model 2 predicts that Cubans are approximately 3.5 percent more likely to be self-employed compared to a statistically similar African immigrant. When the immigrant proportion ratio is added, Cubans are found to be no more likely to be self-employed than African immigrants. That is, the difference in selfemployment rates between Cuban and African immigrants possessing similar 
individual characteristics can be explained completely by the proportion of conationals living in the area.

The last model presented in Table 7, Model 4, adds to the previous model two instruments measuring the ratio of self-employment earnings to wage/salary earnings. The first variable is calculated by dividing the average native self-employment earnings in the SMSA in a given census year by the average native wage/salary earnings in the same SMSA and by natives' ethnicity ${ }^{8}$. The second variable measures the same ratio, but for immigrants by SMSA and national origin group. The latter variable is set to zero for all natives and the former is set to zero for all immigrants. It is expected that higher self-employment earnings to wage/salary earnings ratios are associated with higher self-employment rates, given a set of individual characteristics, since it essentially measures the relative success of the self-employed in the area $\mathrm{Q}^{\mathrm{O}}$. The signs of both of the estimated coefficients are positive, as expected, and significant. However, the impact of a change in the earnings ratio on the probability of selfemployment appears to be stronger for immigrants than natives. An increase in the earnings ratio by 0.1 increases the probability of self-employment for natives by 0.17 percent. The effect of the same change in the ratio on a Mexican immigrant who arrived between 1975 and 1979 is an increase in the probability of self-employment by

\footnotetext{
${ }^{8}$ The ethnic groups used are the ones shown in Table A2, i.e. white, black, Asian, Hispanic and all other.

${ }^{9}$ One concern with incorporating these variables into the self-employment decision models is that they may be determined endogenously and consequently lead to inconsistent estimators. However, given that the ratios are relative group characteristics by SMSA and not individual characteristics, this seems somewhat unlikely. The earnings ratio is not clearly endogenous, but may simply reflect entrepreneurial conditions or opportunities in an area.
} 


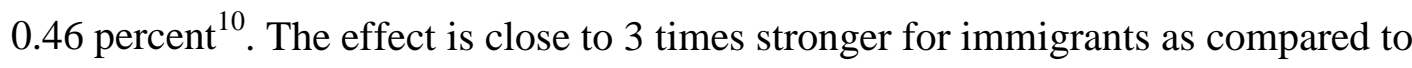
natives. The overall entrepreneurial success of an immigrant's co-nationals in the area seems to be quite important in the self-employment decision process. Natives are less influenced by the relative rewards between self-employment and wage/salary work in the area than immigrants.

The models described above show that it is important to include controls for country of origin when analyzing the self-employment decision. They also show differences in the role of education and earnings ratios in the self-employment choice process between immigrants and natives. The specification in Model 4 is used for the two-step Heckman selection correction models estimated and described below.

\section{Empirical Model and Findings: Labor Market Assimilation}

Immigrants' earnings in the wage/salary sector have been found not to converge with natives' earnings (Borjas, 1985 and 1995) over the work life. Earnings of immigrants start out at a lower point and rise more rapidly over time than natives' earnings. However, parity is not reached. This section will look at whether this also holds for self-employed immigrants when compared to self-employed natives. Comparisons of immigrant labor market performance between the two sectors will also be made.

\footnotetext{
${ }^{10}$ The interquartile range for the earnings ratios are approximately 0.4 for immigrants and 0.15 for natives. This implies that the model predicts roughly 1.8 percent of the variation in immigrant selfemployment rates over SMSAs and 0.25 percent of the variation in native self-employment rates.
} 
The earnings models estimated in this paper use as the dependent variable log of weekly earnings 11 . To try to take into account the possibility that self-employed workers earn a return on physical capital, I also estimate models using as the dependent variable the log of weekly income, which includes any earnings from wage/salary work and/or self-employment earnings and in addition any interest, rental or dividend income. If an individual is deciding between a wage/salary job or selfemployment, he/she can keep his/her assets in, for example, savings accounts, the stock market, bonds, or real estate and work in the wage/salary sector. Alternatively he/she can use a proportion, or all, of his/her assets to start a business. In the former, returns to physical capital will be observed in terms of interest, rental or dividend income. If self-employment is chosen, returns may show up both in increased earnings and interest, rental or dividend income. Therefore, as an alternative outcome measure, I use log income, where income is sum of total earnings and interest, rental or dividend income. With this measure, both groups are put on "par", and this measure of income can be compared reasonably between the two sectors. It appears that the results are not very sensitive to whether earnings or income is used. In light of this, I use the log of weekly earnings as the dependent variable in all wage regressions presented and discussed in this paper. Furthermore, all earnings are deflated to 1989 dollars using the CPI.

\footnotetext{
${ }^{11}$ Weekly earnings are calculated by adding up a person's earnings from wage/salary work and selfemployment. This is divided by the number of weeks worked to obtain weekly earnings. Note that an individual may report earnings from both wage/salary work and self-employment. In these cases, both sources are included in the sum of earnings. In 1980 earnings were top coded at $\$ 75,000$ while in 1990 the top code was $\$ 140,000$. The real difference between the top code is approximately 10 percent. The reported top coded earnings in 1980 are adjusted by multiplying them by 1.1 .
} 
One convenient way of analyzing labor market assimilation is to estimate earnings equations and use the estimated coefficients to trace out age-earnings profiles or alternatively use the predicted earnings to derive the profiles. The wage models are estimated separately for the self-employed and the wage/salary workers. The regressions are specified as:

$$
\begin{array}{ll}
\log y_{i}^{s-e}=\mathbf{x}_{i} \beta^{s-e}+\mathbf{A}_{i} \delta^{s-e}+\mathbf{Y S M}_{i} \gamma^{s-e}+\varepsilon_{i}^{s-e}, & \text { for the self-employed } \\
\log y_{i}^{w / s}=\mathbf{x}_{i} \beta^{w / s}+\mathbf{A}_{i} \delta^{w / s}+\mathbf{Y S M}_{i} \gamma^{w / s}+\varepsilon_{i}^{w / s}, & \text { for wage/salary workers }
\end{array}
$$

where $\mathbf{X}$ is a vector of socio-economic and geographic characteristics, including dummy variables for immigrant status, national origin group and arrival cohort, $\mathbf{A}$ is a vector of age variables, i.e. age, $\mathrm{age}^{2}$ and $\mathrm{age}^{3}$, and YSM is a vector of years since migration variables, i.e. YSM, YSM ${ }^{2}$ and YSM $^{3}$. The vector $\mathbf{A}$ also includes the age variables interacted with an immigrant dummy variable. The years since migration variable is equal to zero for all natives.

The models described above were estimated both by ordinary least squares with no correction and also by heteroskedastic robust ordinary least squares using the inverse Mills ratio to correct for selection bias. The estimated coefficients from the earnings models are presented in Table 8 where Model 1 is the equation without correction and Model 2 includes the correction term calculated based on estimation of Model 4 in Table 7.

The sign of the coefficient on the inverse Mills ratio variable tells us whether there is an overall positive or negative selection into each sector. Not surprisingly, the correction term indicates that there is positive selection into both wage/salary work 
and self-employment ${ }^{12}$. That is, individuals who choose self-employment are better suited for self-employment, at least in terms of earnings, than are the persons who choose to work in the wage/salary sector and vice versa. Fairlie and Meyer (1994) also find indication of positive selection into both sectors. However, the coefficient on the correction term for the self-employed is not found to be statistically significant in their study, which does not include any instrumental variables.

Comparing the estimated coefficients from the models with and without correction for selectivity gives further insight to the selection process. The coefficients on the national origin group dummies suggest that selection into self-employment varies over these groups. This is indicated by the differences in the coefficients when selection is controlled for. For wage/salary immigrants in two of the national origin groups, North East Asia and Middle East, the coefficients reverse sign from positive to negative. For the self-employed North East Asians, the sign switches from negative to positive.

The coefficient for limited English proficiency is of similar magnitude in both sectors in the models without correction. When correction is controlled for, the estimated coefficient does not change much for wage/salary workers but becomes substantially greater in absolute terms for the self-employed. The higher penalty for limited English ability in the self-employment sector may be one of the reasons for the observed lower proportion of individuals with this proficiency level of English among the self-employed.

\footnotetext{
12 The signs of the coefficients of the correction term in table 7 indicate the sign of the bias. This is the case since two probits, one for the probability of self-employment and one for the probability of wage/salary work, were estimated in order to calculate the inverse Mills ratio. The signs of the estimated probit coefficients in the two models are simply the negative of each other.
} 
Returns to education appear to be greater for self-employed immigrants and natives, as compared to wage/salary employees, both in models with and without a correction term. Also, the effect of controlling for self selection is much greater on the schooling coefficient for the self-employed. As was found in Betts and Lofstrom (1998), returns to education for immigrants are lower than for natives. The returns from an additional year of schooling are greater for self-employed immigrants compared to wage/salary immigrants. However, when selection is controlled for it appears that immigrant education is discounted to a greater extent for the selfemployed.

The self-employment decision models indicate that age affects self-employment probabilities differently between immigrants and natives. One possible reason for this is that age also impacts earnings differently for immigrants and natives. Model 1 in Table 8 suggest that this is the case and that there are also differences in returns to experience, or age, between the two sectors. For immigrants it also appears that years since migration impacts earnings differently between the self-employed and wage/salary workers. Since the models allow for non-linearities in both age and years since migration, it is difficult to analyze labor market assimilation by a simple comparison of the estimated coefficients. Instead, as stated above, a convenient way to analyze this is to look at age-earnings profiles. Figure 1 shows the predicted ageearnings profiles derived from Model 1. It traces out the average predicted log weekly earnings over age. In other words, the estimated coefficients from Model 1 are used to calculate the predicted earnings for each individual by age for the four groups, selfemployed immigrants and natives and, wage/salary immigrants and natives. 
The age-earnings profiles suggest that both wage/salary and self-employed immigrants start out at lower earnings than natives. They also indicate that wage/salary immigrants never reach earnings parity with natives. This supports the findings by Borjas (1995). A very interesting finding here is that self-employed immigrants' earnings appear to catch up with wage/salary natives' earnings at around age 30 and overtake, but stay close to, self-employed natives' earnings at around age 40. The greater labor market assimilation rate of self-employed immigrants, as compared to wage/salary immigrants, allows these immigrants to overcome their initial earnings disadvantage compared to wage/salary immigrants and natives and self-employed natives. As can be seen in Figure 2, this also holds true when correction for self selection is incorporated into the model. Figure 2 shows the predicted ageearnings profile obtained from Model 2 in Table 8.

The finding that self-employed immigrants display greater earnings growth than wage/salary immigrants suggests that the wage gap between natives and immigrants is measured somewhat inaccurately unless self-employed immigrants are included in the sample. The important question is then: how does this gap change when the selfemployed are included? One way to answer this question is to calculate "weighted" age-earnings profiles separately for immigrants and natives in the following way:

$$
\bar{y}_{j}^{k}=\frac{n_{j}^{w / s}}{n_{j}} \hat{y}_{j}^{w / s}+\frac{n_{j}^{s-e}}{n_{j}} \hat{y}_{j}^{s-e}
$$

where $n$ is the number of individuals in age group $j, j$ varies between 17 and 63, and where $k$ indicates the group, i.e. immigrants or natives. I suppress the superscript on the right hand side variables to simplify the notation. By subtracting $\bar{y}_{j}^{\text {immigrants }}$ from 
$\bar{y}_{j}^{\text {natives }}$ the wage gap when the self-employed are included can be calculated for each age group. Figure 3 shows the log wage gap calculated in this way, based on Model 2 in Table 8 , and also the log wage gap when the self-employed are excluded.

The immigrant native earnings gap changes very little for individuals under the age of 30 when the self-employed are included. However, the gap becomes more exaggerated with age and is most overstated for individuals in their fifties. Excluding the self-employed when studying labor market assimilation overstates the gap between natives and immigrants by up to 30 percent of the earnings gap. This is mainly driven by two components. The first is that the most successful self-employed immigrants, relative to natives, are 40 years old or older. The second reason can be seen in Figure 4. The greatest difference in self-employment rates between natives and immigrants is for individuals in their forties and fifties. The observed overall higher selfemployment rate among immigrants is caused by the higher self-employment rates of this age group. It is not surprising that the most successful self-employed immigrants, relative to natives, also have the highest relative self-employment rates. This is in fact what the theoretical model described above predicts.

Using the predicted earnings and the method described above, I also calculate the overall average immigrant-native earnings gap both when the self-employed are excluded and included in the sample. The gap is overstated on average by slightly more than 14 percent when the self-employed are not accounted for in the sample.

The estimated earnings models for wage/salary workers and the self-employed that include a correction term, Model 2 in Table 8, can also be used to predict earnings of the self-employed had they chosen the wage/salary sector. This gives us further 
insight into the effects of self-selection. Figure 5 displays the predicted age-earnings profile for wage/salary workers and the predicted age-earnings profiles for the selfemployed had they chosen wage/salary work. These are calculated by applying the estimated coefficients for wage/salary workers and individuals' inverse Mills ratio to the self-employed as well as wage/salary employees. The predicted wage/salary earnings indicate that self-employed immigrants would barely reach earnings parity with wage/salary natives if they had selected the wage/salary sector. Furthermore, convergence is now delayed until approximately age 55 . The predicted wage/salary earnings of self-employed immigrants is estimated to never reach the predicted wage/salary earnings of self-employed natives. Self-employed immigrants are predicted to do worse in the wage/salary sector compared to self-employed natives. Self-employed immigrants appear to be relatively more positively selected into selfemployment than natives.

Is it possible that cohort effects may be the reason labor market assimilation appears to be more rapid for self-employed immigrants? It has been suggested that the drop in relative labor market performance of immigrants in the last decades is due to changes in U.S. immigration policy (see for example Borjas 1994). The 1965 Amendments to the Immigration and Nationality Act repealed the national origin restrictions and made family re-unification the main criteria in deciding who is allowed to immigrate to the U.S. The effect of the policy change is believed to have led to changes in the national origin composition of immigrants toward immigrants of lower skill levels. 
To ensure that cohort effects are not the cause of the observed relative attainment of self-employed immigrants, separate age-earnings profiles were derived for post 1965 arrival cohorts and 1965 and before arrival cohorts. Figure 6 shows these ageearnings profiles. It can be seen that the more recent arrival cohorts do not perform as well in the labor market as the earlier cohorts $\frac{13}{13}$. However, recent self-employed immigrants still do substantially better in the labor market than wage/salary immigrants. Their assimilation rate is greater and they also appear to be close to reaching earnings parity with self-employed natives. Self-employed immigrants who arrived in the earlier cohorts are also better performers in the labor market than wage/salary immigrants who arrived prior to 1965 . The difference in earnings between post 1965 arrival cohorts and earlier cohorts appear to be smaller for self-employed immigrants.

Self-employed immigrants also appear to do better in the labor market than wage/salary immigrants when compared to natives of the same age. Figure 7 shows the predicted average weekly earnings for immigrants of two age groups, 25-34 and 45-54 year olds, relative to natives' average predicted earnings of the same age group. Although not presented here, the general findings for these age groups also hold for other age groups. For virtually all age groups and cohorts, self-employed immigrants perform better in the labor market, relative to natives of the same age, than immigrants in the wage/salary sector. For example, self-employed natives aged 25-34 in 1990 are predicted to earn 18 percent more than self-employed immigrants in this age group

\footnotetext{
${ }^{13}$ One possible reason for the higher earnings of the earlier arrival cohorts is that they consist of a greater proportion of immigrants who migrated at a relatively young age. Borjas (1995) finds that the
} 
who arrived in the U.S. between 1980 and 1984 (i.e. a ratio of approximately 1.18). Wage/salary natives of the same age are predicted to earn 30 percent more than wage/salary immigrants in this age group and who arrived in the $1980-84$ period. The finding that self-employed immigrants display higher relative earnings than immigrant employees appear to hold for both the earlier and the more recent arrival cohorts.

It seems unlikely that any cohort effects that are not absorbed by the estimated models are the driving forces behind the observed relative success of self-employed immigrants.

\section{Conclusion and Summary}

Using data from the 1980 and 1990 U.S. Censuses, this paper shows that there are substantial differences between wage/salary immigrants and self-employed immigrants in terms of earnings and characteristics such as educational attainment. Self-employed immigrants have higher earnings, are more educated and display lower rates of limited English proficiency levels than wage/salary immigrants. Immigrants are more likely to be self-employed than natives but self-employment rates vary greatly across national origin groups and arrival cohorts.

Earnings of both self-employed and wage/salary immigrants declined relative to natives in the 1980's. The relative decline appears to be slightly stronger among the immigrants who chose wage/salary work.

assimilation process of immigrants who arrive in the U.S. at a young age have age-earnings profiles that are similar to the age-earnings profiles of natives. 
Models of the self-employment decision are also estimated. Controlling for national origin groups affects the estimated impact of years of education on selfemployment probabilities. Evidence of different roles of years of schooling in the selfemployment decision between natives and immigrants is also found. Education has a greater influence on natives' self-employment probabilities compared to immigrants'.

The paper also finds evidence that the proportion of co-nationals living in the same SMSA has a positive impact on self-employment probabilities for immigrants. This variable alone appears to explain differences in self-employment rates between Cuban immigrants and African immigrants. This supports Borjas' (1986) finding of enclave effects in explaining some of the differences in self-employment rates between natives and immigrants.

The ratio of average self-employment earnings to wage/salary earnings in an individual's SMSA affects self-employment rates of natives substantially less than it does for immigrants.

The estimated earnings models suggest that wage/salary immigrants will not reach earnings parity with wage/salary natives. Earnings of self-employed immigrants are predicted to converge with native wage/salary earnings at around age 30 and native self-employed earnings at around age 40. The higher earnings of the self-employed suggest that the immigrant native earnings gap is overstated if the self-employed are not included in the sample. Calculations indicate the gap may be overstated by up to 30 percent for some age groups, but on average, the gap is overstated by roughly 14 percent. 
Estimated models with correction for self-selectivity indicate that self-employed immigrants would not reach earnings parity with self-employed natives would they have chosen to work in the wage/salary sector. The greater relative difference for immigrants between expected earnings in the wage/salary sector and self-employment earnings, compared to the difference for natives, is quite plausibly one important reason why immigrants display overall higher self-employment rates. 


\section{References}

Aldrich, Howard E. and Waldinger, Roger. "Ethnicity and Entrepreneurship," Annual Review of Sociology, 1990, 16, 111-35.

Aronson, Robert L. Self-Employment: A Labor Market Perspective, Ithaca, ILR Press, 1991.

Betts, Julian R. and Lofstrom, Magnus “The Educational Attainment of Immigrants: Trends and Implications,” NBER Working Paper No. 6757, October 1998.

Borjas, George J. "Assimilation Changes in Cohort Quality and the Earnings of Immigrants," Journal of Labor Economics, October. 1985, 4, 463-89.

Borjas, George J. "The Self-Employment Experience of Immigrants," Journal of Human Resources, 1986, 21, 485-506.

Borjas, George J. "Self-Selection and the earnings of Immigrants," The American Economic Review, September 1987, 4, 531-53.

Borjas, George J. Friends or Strangers: The Impact of Immigrants on the U.S. Economy. New York: Basic Books, 1990.

Borjas, George J. "The Economics of Immigration," Journal of Economic Literature, December 1994, 32, 1667-717.

Borjas, George J. “Assimilation Changes in Cohort Quality Revisited: What Happened to Immigrant Earnings in the 1980's?" Journal of Labor Economics, April 1995, 2, 201-45.

Borjas, George J. and Bronars, Stephen G. "Consumer Discrimination and SelfEmployment," Journal of Political Economy, 1989, 97, 581-605.

Borjas, George J. and Bronars, Stephen G. "Immigration and the Family" Journal of Labor Economics, April 1991, 2, 123-78.

Bregger, John E. "Measuring Self-employment in the United States," Monthly Labor Review, January/February 1996, 3-9.

Carliner, Geoffrey. "Wages, Earnings and Hours of First, Second, and Third Generation American Males," Economic Inquiry, January 1980, 1, 87-102.

Chiswick, Barry R. "The Effect of Americanization on the Earnings of Foreign-born Men," Journal of Political Economy, October 1978, 5, 897-921. 
Cummings, Scott, ed. Self-Help in Urban America: Patterns of Minority Business Enterprise, New York, Kenikart Press, 1980.

Fairlie, Robert W. and Meyer, Bruce D. "The Ethnic and Racial Character of SelfEmployment," National Bureau of Economic Research, Working Paper No. 4791, July 1994.

Fairlie, Robert W. and Meyer, Bruce D. "Ethnic and Racial Self-Employment Differences and Possible Explanations," Journal of Human Resources, 1996, 31, 757-93.

Light, Ivan "Immigrant and Ethnic Enterprise in North America," Ethnic and Racial Studies, 1984, 7, 195-216.

Yuengert, Andrew M. "Testing Hypotheses of Immigrant Self-Employment," Journal of Human Resources, 1995, 30, 194-204. 
Table 1

Self-employment Rates by National Origin Group and Arrival Cohort.

\begin{tabular}{|c|c|c|c|c|c|c|c|}
\hline \multirow[b]{3}{*}{ Group: } & \multicolumn{4}{|c|}{ National Origin Group: } & \multicolumn{3}{|c|}{ Arrival Cohort: } \\
\hline & \multicolumn{2}{|c|}{ Sample Size } & \multicolumn{2}{|c|}{$\begin{array}{c}\text { Self-Employment } \\
\text { Rates }\end{array}$} & \multirow[b]{2}{*}{ Group: } & \multicolumn{2}{|c|}{$\begin{array}{c}\text { Self-Employment } \\
\text { Rates }\end{array}$} \\
\hline & 1980 & 1990 & 1980 & 1990 & & 1980 & 1990 \\
\hline Natives & 472046 & 489821 & $10.39 \%$ & $11.21 \%$ & & & \\
\hline All Immigrants & 151010 & 229902 & $11.63 \%$ & $12.20 \%$ & & & \\
\hline National Origin Group: & & & & & Cohort: & & \\
\hline Mexico & 31360 & 66972 & $4.12 \%$ & $5.67 \%$ & 1985-89 Arrivals & & $6.12 \%$ \\
\hline Central/South America & 11554 & 26184 & $8.34 \%$ & $9.12 \%$ & 1980-84 Arrivals & & $10.01 \%$ \\
\hline South East Asia & 9070 & 20181 & $6.55 \%$ & $7.85 \%$ & 1975-79 Arrivals & $5.95 \%$ & $12.73 \%$ \\
\hline North East Asia & 10215 & 19069 & $17.25 \%$ & $20.55 \%$ & 1970-74 Arrivals & $9.44 \%$ & $14.54 \%$ \\
\hline India, Pakistan, etc & 4518 & 9190 & $11.44 \%$ & $13.99 \%$ & 1965-69 Arrivals & $11.48 \%$ & $15.00 \%$ \\
\hline Middle East/Egypt & 4402 & 9950 & $22.54 \%$ & $24.54 \%$ & 1960-64 Arrivals & $13.35 \%$ & $17.05 \%$ \\
\hline Europe,CAN,AUS,NZ & 61663 & 52897 & $15.41 \%$ & $17.60 \%$ & 1950-59 Arrivals & $14.86 \%$ & $18.05 \%$ \\
\hline Africa & 1756 & 3838 & $12.59 \%$ & $13.07 \%$ & Pre-1950 Arrivals & $18.23 \%$ & $19.28 \%$ \\
\hline Caribbean & 7780 & 11342 & $5.18 \%$ & $8.04 \%$ & & & \\
\hline Cuba & 8692 & 10279 & $15.24 \%$ & $17.72 \%$ & & & \\
\hline
\end{tabular}




\section{Table 2}

\section{Annual Earnings, Mean and Ratio 90th/10th Percentile, by Arrival Cohort.}

Note: Earnings are shown in 1989 dollars and are adjusted for inflation by the annual Consumer Price Index

\begin{tabular}{|c|c|c|c|c|c|c|c|c|}
\hline \multirow[b]{3}{*}{ Group } & \multicolumn{4}{|c|}{1980} & \multicolumn{4}{|c|}{1990} \\
\hline & \multicolumn{2}{|c|}{ Self-employed } & \multicolumn{2}{|c|}{ Wage/Salary } & \multicolumn{2}{|c|}{ Self-employed } & \multicolumn{2}{|c|}{ Wage/Salary } \\
\hline & Mean & $\mathrm{P} 90 / 10$ & Mean & $\mathrm{P} 90 / 10$ & Mean & $\mathrm{P} 90 / 10$ & Mean & $\mathrm{P} 90 / 10$ \\
\hline Natives & 40,388 & 11.12 & 28,459 & 5.75 & 41,993 & 14.29 & 29,378 & 6.78 \\
\hline All Immigrants & 42,246 & 11.53 & 26,841 & 6.42 & 41,364 & 14.09 & 25,479 & 8.33 \\
\hline Ratio: Natives $\div$ Immigrants & 0.956 & 0.965 & 1.060 & 0.895 & 1.015 & 1.014 & 1.153 & 0.813 \\
\hline \multicolumn{9}{|l|}{ Cohort: } \\
\hline 1985-89 Arrivals & & & & & 25,462 & 13.75 & 18,253 & 9.34 \\
\hline 1980-84 Arrivals & & & & & 31,464 & 11.00 & 20,604 & 6.67 \\
\hline 1975-79 Arrivals & 32,295 & 13.72 & 19,800 & 8.66 & 40,582 & 12.50 & 24,782 & 6.70 \\
\hline 1970-74 Arrivals & 38,534 & 10.79 & 22,954 & 5.21 & 45,492 & 15.44 & 27,303 & 6.94 \\
\hline 1965-69 Arrivals & 42,589 & 11.23 & 27,018 & 5.60 & 47,272 & 13.72 & 31,245 & 6.29 \\
\hline 1960-64 Arrivals & 44,845 & 9.99 & 29,357 & 5.45 & 48,700 & 13.72 & 35,229 & 6.44 \\
\hline 1950-59 Arrivals & 43,900 & 9.99 & 32,374 & 4.56 & 48,003 & 12.15 & 37,728 & 5.91 \\
\hline Pre-1950 Arrivals & 46,516 & 11.16 & 35,391 & 5.14 & 55,467 & 16.17 & 40,301 & 7.65 \\
\hline
\end{tabular}


Table 3

Annual Earnings, Mean and Ratio 90th/10th Percentile, by National Origin Group.

Note: Earnings are shown in 1989 dollars and are adjusted for inflation by the annual Consumer Price Index

\begin{tabular}{|c|c|c|c|c|c|c|c|c|}
\hline \multirow[b]{3}{*}{ Group } & \multicolumn{4}{|c|}{1980} & \multicolumn{4}{|c|}{1990} \\
\hline & \multicolumn{2}{|c|}{ Self-employed } & \multicolumn{2}{|c|}{ Wage/Salary } & \multicolumn{2}{|c|}{ Self-employed } & \multicolumn{2}{|c|}{ Wage/Salary } \\
\hline & Mean & $\mathrm{P} 90 / 10$ & Mean & $\mathrm{P} 90 / 10$ & Mean & $\mathrm{P} 90 / 10$ & Mean & $\mathrm{P} 90 / 10$ \\
\hline Natives & 40,388 & 11.12 & 28,459 & 5.75 & 41,993 & 14.29 & 29,378 & 6.78 \\
\hline All Immigrants & 42,246 & 11.53 & 26,841 & 6.42 & 41,364 & 14.09 & 25,479 & 8.33 \\
\hline Ratio: Natives $\div$ Immigrants & 0.956 & 0.965 & 1.060 & 0.895 & 1.015 & 1.014 & 1.153 & 0.813 \\
\hline \multicolumn{9}{|l|}{ National Origin Group: } \\
\hline Mexico & 27,708 & 8.70 & 17,702 & 5.93 & 21,957 & 9.93 & 14,807 & 6.09 \\
\hline Central/South America & 40,880 & 11.99 & 23,253 & 6.24 & 34,076 & 13.00 & 20,653 & 6.50 \\
\hline South East Asia & 65,046 & 15.70 & 23,919 & 6.00 & 45,022 & 20.59 & 24,478 & 6.26 \\
\hline North East Asia & 39,582 & 11.35 & 29,714 & 7.38 & 42,441 & 10.75 & 33,561 & 9.07 \\
\hline India, Pakistan, etc & 65,000 & 11.23 & 35,788 & 5.98 & 69,864 & 19.48 & 36,813 & 7.78 \\
\hline Middle East/Egypt & 46,753 & 13.26 & 30,016 & 6.72 & 48,299 & 12.35 & 34,830 & 7.30 \\
\hline Europe,CAN,AUS,NZ & 42,628 & 9.16 & 33,152 & 5.42 & 46,487 & 11.67 & 37,733 & 6.18 \\
\hline Africa & 47,517 & 13.20 & 29,259 & 7.10 & 43,328 & 15.44 & 29,823 & 7.35 \\
\hline Caribbean & 33,882 & 11.22 & 19,949 & 5.90 & 27,348 & 9.67 & 21,324 & 6.67 \\
\hline Cuba & 37,395 & 10.19 & 24,750 & 5.00 & 35,912 & 11.43 & 25,806 & 6.71 \\
\hline
\end{tabular}


Table 4

Educational Attainment and English Proficiency - Immigrants and Natives.

\begin{tabular}{|c|c|c|c|c|c|c|c|c|}
\hline \multirow[b]{2}{*}{ Group } & \multicolumn{4}{|c|}{ Self-Employed } & \multicolumn{4}{|c|}{ Wage/Salary } \\
\hline & $\begin{array}{l}\text { Years of } \\
\text { Schooling }\end{array}$ & $\begin{array}{c}\text { High School } \\
\text { Drop Out }\end{array}$ & $\begin{array}{l}\text { College } \\
\text { Graduate }\end{array}$ & $\begin{array}{l}\text { Limited } \\
\text { English }\end{array}$ & $\begin{array}{l}\text { Years of } \\
\text { Schooling }\end{array}$ & $\begin{array}{c}\text { High School } \\
\text { Drop Out }\end{array}$ & $\begin{array}{l}\text { College } \\
\text { Graduate }\end{array}$ & $\begin{array}{l}\text { Limited } \\
\text { English }\end{array}$ \\
\hline & & 1980 & & & & 1980 & & \\
\hline Natives & 13.30 & $20.4 \%$ & $29.1 \%$ & $N / A$ & 12.55 & $23.5 \%$ & $19.6 \%$ & $\mathrm{~N} / \mathrm{A}$ \\
\hline All Immigrants & 12.82 & $29.4 \%$ & $30.6 \%$ & $11.2 \%$ & 11.55 & $39.4 \%$ & $22.5 \%$ & $22.6 \%$ \\
\hline Ratio: Natives $\div$ Immigrants & 1.04 & 0.69 & 0.95 & $N / A$ & 1.09 & 0.60 & 0.87 & $\mathrm{~N} / \mathrm{A}$ \\
\hline & & 1990 & & & & 1990 & & \\
\hline Natives & 13.65 & $14.1 \%$ & $31.9 \%$ & $N / A$ & 13.00 & $16.2 \%$ & $23.6 \%$ & $N / A$ \\
\hline All Immigrants & 12.64 & $28.9 \%$ & $32.3 \%$ & $16.7 \%$ & 11.14 & $41.5 \%$ & $23.3 \%$ & $26.7 \%$ \\
\hline Ratio: Natives $\div$ Immigrants & 1.08 & 0.49 & 0.99 & $\mathrm{~N} / \mathrm{A}$ & 1.17 & 0.39 & 1.02 & $\mathrm{~N} / \mathrm{A}$ \\
\hline
\end{tabular}


Table 5

Educational Attainment and English Proficiency by Arrival Cohort.

\begin{tabular}{|c|c|c|c|c|c|c|c|c|}
\hline \multirow[b]{2}{*}{ Group } & \multicolumn{4}{|c|}{ Self-Employed } & \multicolumn{4}{|c|}{ Wage/Salary } \\
\hline & $\begin{array}{c}\text { Years of } \\
\text { Schooling }\end{array}$ & $\begin{array}{c}\text { High School } \\
\text { Drop Out }\end{array}$ & $\begin{array}{l}\text { College } \\
\text { Graduate }\end{array}$ & $\begin{array}{l}\text { Limited } \\
\text { English }\end{array}$ & $\begin{array}{c}\text { Years of } \\
\text { Schooling }\end{array}$ & $\begin{array}{c}\text { High School } \\
\text { Drop Out }\end{array}$ & $\begin{array}{l}\text { College } \\
\text { Graduate }\end{array}$ & $\begin{array}{l}\text { Limited } \\
\text { English }\end{array}$ \\
\hline Cohort: & \multicolumn{4}{|c|}{1980} & \multicolumn{4}{|c|}{1980} \\
\hline 1975-79 Arrivals & 13.22 & $24.3 \%$ & $37.0 \%$ & $25.4 \%$ & 11.13 & $44.6 \%$ & $23.5 \%$ & $41.9 \%$ \\
\hline 1970-74 Arrivals & 13.01 & $29.2 \%$ & $36.0 \%$ & $18.7 \%$ & 10.91 & $47.1 \%$ & $21.1 \%$ & $31.0 \%$ \\
\hline 1965-69 Arrivals & 12.87 & $31.7 \%$ & $33.1 \%$ & $15.1 \%$ & 11.49 & $41.4 \%$ & $22.5 \%$ & $22.4 \%$ \\
\hline 1960-64 Arrivals & 12.84 & $29.0 \%$ & $29.3 \%$ & $10.3 \%$ & 11.97 & $33.8 \%$ & $22.1 \%$ & $13.9 \%$ \\
\hline 1950-59 Arrivals & 12.51 & $30.2 \%$ & $25.8 \%$ & $5.2 \%$ & 12.14 & $30.9 \%$ & $22.9 \%$ & $7.7 \%$ \\
\hline \multirow[t]{2}{*}{ Pre-1950 Arrivals } & 12.78 & $29.8 \%$ & $27.8 \%$ & $2.0 \%$ & 12.14 & $33.4 \%$ & $22.7 \%$ & $4.6 \%$ \\
\hline & \multicolumn{4}{|c|}{1990} & \multicolumn{4}{|c|}{1990} \\
\hline 1985-89 Arrivals & 12.03 & $31.9 \%$ & $29.3 \%$ & $36.5 \%$ & 10.71 & $46.7 \%$ & $22.1 \%$ & $45.9 \%$ \\
\hline 1980-84 Arrivals & 12.24 & $30.4 \%$ & $28.8 \%$ & $27.6 \%$ & 10.65 & $46.6 \%$ & $20.2 \%$ & $33.1 \%$ \\
\hline 1975-79 Arrivals & 12.89 & $25.6 \%$ & $36.6 \%$ & $16.2 \%$ & 10.85 & $44.1 \%$ & $23.3 \%$ & $24.1 \%$ \\
\hline 1970-74 Arrivals & 12.58 & $31.8 \%$ & $33.7 \%$ & $15.5 \%$ & 10.90 & $44.0 \%$ & $22.5 \%$ & $21.0 \%$ \\
\hline 1965-69 Arrivals & 12.64 & $31.4 \%$ & $31.0 \%$ & $12.1 \%$ & 11.78 & $35.0 \%$ & $25.3 \%$ & $14.7 \%$ \\
\hline 1960-64 Arrivals & 12.90 & $26.6 \%$ & $32.0 \%$ & $7.4 \%$ & 12.36 & $28.4 \%$ & $27.9 \%$ & $10.0 \%$ \\
\hline 1950-59 Arrivals & 12.99 & $26.9 \%$ & $31.7 \%$ & $3.8 \%$ & 12.44 & $26.7 \%$ & $27.3 \%$ & $5.9 \%$ \\
\hline Pre-1950 Arrivals & 13.54 & $21.8 \%$ & $38.7 \%$ & $3.3 \%$ & 12.68 & $25.6 \%$ & $31.8 \%$ & $4.5 \%$ \\
\hline
\end{tabular}


Table 6

Educational Attainment and English Proficiency by National Origin Group.

\begin{tabular}{|c|c|c|c|c|c|c|c|c|}
\hline \multirow[b]{2}{*}{ National Origin Group: } & \multicolumn{4}{|c|}{ Self-Employed } & \multicolumn{4}{|c|}{ Wage/Salary } \\
\hline & $\begin{array}{l}\text { Years of } \\
\text { Schooling }\end{array}$ & $\begin{array}{c}\text { High School } \\
\text { Drop Out }\end{array}$ & $\begin{array}{l}\text { College } \\
\text { Graduate }\end{array}$ & $\begin{array}{l}\text { Limited } \\
\text { English }\end{array}$ & $\begin{array}{l}\text { Years of } \\
\text { Schooling }\end{array}$ & $\begin{array}{l}\text { High School } \\
\text { Drop Out }\end{array}$ & $\begin{array}{l}\text { College } \\
\text { Graduate }\end{array}$ & $\begin{array}{l}\text { Limited } \\
\text { English }\end{array}$ \\
\hline & \multicolumn{4}{|c|}{1980} & \multicolumn{4}{|c|}{1980} \\
\hline Mexico & 9.20 & $62.1 \%$ & $10.1 \%$ & $33.9 \%$ & 7.73 & $76.1 \%$ & $2.8 \%$ & $52.1 \%$ \\
\hline Central/South America & 13.56 & $21.7 \%$ & $31.7 \%$ & $12.8 \%$ & 11.85 & $34.6 \%$ & $17.1 \%$ & $25.2 \%$ \\
\hline South East Asia & 16.84 & $6.6 \%$ & $72.2 \%$ & $5.9 \%$ & 13.59 & $18.4 \%$ & $37.1 \%$ & $11.3 \%$ \\
\hline North East Asia & 14.43 & $15.1 \%$ & $51.4 \%$ & $23.3 \%$ & 14.41 & $16.3 \%$ & $51.1 \%$ & $24.4 \%$ \\
\hline India, Pakistan, etc & 17.39 & $5.2 \%$ & $78.0 \%$ & $1.2 \%$ & 17.08 & $6.1 \%$ & $77.9 \%$ & $2.6 \%$ \\
\hline Middle East/Egypt & 13.61 & $23.2 \%$ & $36.0 \%$ & $5.6 \%$ & 13.86 & $21.3 \%$ & $42.1 \%$ & $8.5 \%$ \\
\hline Europe,CAN,AUS,NZ & 12.44 & $31.1 \%$ & $24.7 \%$ & $4.6 \%$ & 12.28 & $31.1 \%$ & $23.7 \%$ & $9.1 \%$ \\
\hline Africa & 14.55 & $14.9 \%$ & $43.4 \%$ & $1.4 \%$ & 14.57 & $13.4 \%$ & $46.3 \%$ & $3.5 \%$ \\
\hline Caribbean & 12.23 & $33.5 \%$ & $19.9 \%$ & $11.2 \%$ & 11.18 & $40.1 \%$ & $11.9 \%$ & $15.3 \%$ \\
\hline Cuba & 12.08 & $\begin{array}{r}36.1 \% \\
1990\end{array}$ & $24.6 \%$ & $31.2 \%$ & 11.59 & $\begin{array}{r}37.5 \% \\
1990\end{array}$ & $18.6 \%$ & $32.6 \%$ \\
\hline Mexico & 8.11 & $71.0 \%$ & $6.4 \%$ & $38.5 \%$ & 7.45 & $77.0 \%$ & $2.6 \%$ & $49.7 \%$ \\
\hline Central/South America & 12.35 & $31.1 \%$ & $26.1 \%$ & $23.1 \%$ & 10.75 & $43.8 \%$ & $13.8 \%$ & $32.5 \%$ \\
\hline South East Asia & 14.03 & $18.1 \%$ & $44.6 \%$ & $14.3 \%$ & 12.91 & $20.4 \%$ & $32.7 \%$ & $14.3 \%$ \\
\hline North East Asia & 13.96 & $14.4 \%$ & $46.1 \%$ & $28.8 \%$ & 13.90 & $16.9 \%$ & $49.7 \%$ & $28.1 \%$ \\
\hline India, Pakistan, etc & 16.63 & $5.5 \%$ & $75.1 \%$ & $1.8 \%$ & 15.55 & $9.2 \%$ & $69.1 \%$ & $4.8 \%$ \\
\hline Middle East/Egypt & 14.12 & $15.2 \%$ & $46.4 \%$ & $4.6 \%$ & 14.47 & $12.9 \%$ & $52.7 \%$ & $5.0 \%$ \\
\hline Europe,CAN,AUS,NZ & 12.85 & $25.4 \%$ & $28.8 \%$ & $5.0 \%$ & 12.95 & $23.0 \%$ & $31.6 \%$ & $8.1 \%$ \\
\hline Africa & 14.65 & $10.5 \%$ & $51.2 \%$ & $1.5 \%$ & 14.68 & $9.9 \%$ & $54.4 \%$ & $3.5 \%$ \\
\hline Caribbean & 11.87 & $35.0 \%$ & $18.0 \%$ & $15.2 \%$ & 11.23 & $40.2 \%$ & $12.6 \%$ & $17.3 \%$ \\
\hline Cuba & 11.82 & $39.6 \%$ & $21.7 \%$ & $33.6 \%$ & 11.60 & $38.4 \%$ & $18.1 \%$ & $28.3 \%$ \\
\hline
\end{tabular}


Table 7

Probit Models for Self-Employment for Males Aged 18-64, Based on 1980 and 1990 Public Use Samples of the U.S. Census.

\begin{tabular}{|c|c|c|c|c|}
\hline Variable & Model 1 & Model 2 & Model 3 & Model 4 \\
\hline Constant & $\begin{array}{l}-4.9720 \\
(0.0603)\end{array}$ & $\begin{array}{l}-4.9700 \\
(0.0603)\end{array}$ & $\begin{array}{l}-4.9703 \\
(0.0603)\end{array}$ & $\begin{array}{l}-4.9869 \\
(0.0612)\end{array}$ \\
\hline Immigrant & $\begin{array}{l}1.1556 \\
(0.2242)\end{array}$ & $\begin{array}{l}1.7160 \\
(0.2322)\end{array}$ & $\begin{array}{l}1.7072 \\
(0.2322)\end{array}$ & $\begin{array}{l}1.6247 \\
(0.2363)\end{array}$ \\
\hline Mexico & & $\begin{array}{l}-0.3721 \\
(0.0424)\end{array}$ & $\begin{array}{l}-0.4392 \\
(0.0441)\end{array}$ & $\begin{array}{l}-0.4526 \\
(0.0451)\end{array}$ \\
\hline South and Central America & & $\begin{array}{l}-0.1544 \\
(0.0428)\end{array}$ & $\begin{array}{l}-0.1558 \\
(0.0428)\end{array}$ & $\begin{array}{l}-0.1678 \\
(0.0438)\end{array}$ \\
\hline South East Asia & & $\begin{array}{l}-0.3550 \\
(0.0443)\end{array}$ & $\begin{array}{l}-0.3621 \\
(0.0443)\end{array}$ & $\begin{array}{l}-0.3716 \\
(0.0453)\end{array}$ \\
\hline North East Asia & & $\begin{array}{l}0.2305 \\
(0.0422)\end{array}$ & $\begin{array}{l}0.2280 \\
(0.0422)\end{array}$ & $\begin{array}{l}0.2239 \\
(0.0431)\end{array}$ \\
\hline India/Pakistan & & $\begin{array}{l}-0.0571 \\
(0.0467)\end{array}$ & $\begin{array}{l}-0.0599 \\
(0.0467)\end{array}$ & $\begin{array}{l}-0.0676 \\
(0.0476)\end{array}$ \\
\hline Middle East & & $\begin{array}{l}0.3985 \\
(0.0445)\end{array}$ & $\begin{array}{l}0.3979 \\
(0.0445)\end{array}$ & $\begin{array}{l}0.3925 \\
(0.0454)\end{array}$ \\
\hline Europe/Canada/Australia/New Zealand & & $\begin{array}{l}0.0967 \\
(0.0405)\end{array}$ & $\begin{array}{l}0.0927 \\
(0.0405)\end{array}$ & $\begin{array}{l}0.0920 \\
(0.0413)\end{array}$ \\
\hline Caribbean & & $\begin{array}{l}-0.3065 \\
(0.0465)\end{array}$ & $\begin{array}{l}-0.3115 \\
(0.0466)\end{array}$ & $\begin{array}{l}-0.3197 \\
(0.0475)\end{array}$ \\
\hline Cuba & & $\begin{array}{l}0.1202 \\
(0.0451)\end{array}$ & $\begin{array}{l}0.0144 \\
(0.0489)\end{array}$ & $\begin{array}{l}0.0122 \\
(0.0498)\end{array}$ \\
\hline Period Effect 1980 & $\begin{array}{l}-0.0751 \\
(0.0135)\end{array}$ & $\begin{array}{l}-0.0754 \\
(0.0136)\end{array}$ & $\begin{array}{l}-0.0751 \\
(0.0136)\end{array}$ & $\begin{array}{l}-0.0596 \\
(0.0137)\end{array}$ \\
\hline Age & $\begin{array}{l}0.2075 \\
(0.0048)\end{array}$ & $\begin{array}{l}0.2075 \\
(0.0048)\end{array}$ & $\begin{array}{l}0.2075 \\
(0.0048)\end{array}$ & $\begin{array}{l}0.2059 \\
(0.0048)\end{array}$ \\
\hline Age2 & $\begin{array}{l}-0.0042 \\
(0.0001)\end{array}$ & $\begin{array}{l}-0.0042 \\
(0.0001)\end{array}$ & $\begin{array}{l}-0.0042 \\
(0.0001)\end{array}$ & $\begin{array}{l}-0.0042 \\
(0.0001)\end{array}$ \\
\hline Age3/1000 & $\begin{array}{l}0.2898 \\
(0.0098)\end{array}$ & $\begin{array}{l}0.2898 \\
(0.0098)\end{array}$ & $\begin{array}{l}0.2898 \\
(0.0098)\end{array}$ & $\begin{array}{l}0.2870 \\
(0.0099)\end{array}$ \\
\hline Years of Schooling & $\begin{array}{l}0.0390 \\
(0.0007)\end{array}$ & $\begin{array}{l}0.0390 \\
(0.0007)\end{array}$ & $\begin{array}{l}0.0390 \\
(0.0007)\end{array}$ & $\begin{array}{l}0.0388 \\
(0.0008)\end{array}$ \\
\hline Years of Schooling*Immigrant & $\begin{array}{l}-0.0139 \\
(0.0016)\end{array}$ & $\begin{array}{l}-0.0300 \\
(0.0017)\end{array}$ & $\begin{array}{l}-0.0295 \\
(0.0017)\end{array}$ & $\begin{array}{l}-0.0295 \\
(0.0018)\end{array}$ \\
\hline Age ${ }^{\star}$ Immigrant & $\begin{array}{l}-0.1002 \\
(0.0177)\end{array}$ & $\begin{array}{l}-0.1199 \\
(0.0180)\end{array}$ & $\begin{array}{l}-0.1196 \\
(0.0180)\end{array}$ & $\begin{array}{l}-0.1143 \\
(0.0183)\end{array}$ \\
\hline
\end{tabular}

Continued... 
Table 7 (Continued)

\begin{tabular}{lllll}
\hline Age2*Immigrant & 0.0028 & 0.0032 & 0.0031 & 0.0030 \\
& $(0.0004)$ & $(0.0005)$ & $(0.0005)$ & $(0.0005)$ \\
Age3/1000*Immigrant & -0.2406 & -0.2677 & -0.2670 & -0.2570 \\
& $(0.0361)$ & $(0.0366)$ & $(0.0366)$ & $(0.0371)$ \\
Speaks Little or No English & -0.1262 & -0.0881 & -0.0936 & -0.0961 \\
& $(0.0154)$ & $(0.0162)$ & $(0.0163)$ & $(0.0166)$ \\
Years Since Migration & 0.0352 & 0.0463 & 0.0450 & 0.0450 \\
& $(0.0048)$ & $(0.0049)$ & $(0.0050)$ & $(0.0050)$ \\
Years Since Migration2 & -0.0011 & -0.0012 & -0.0012 & -0.0012 \\
& $(0.0002)$ & $(0.0002)$ & $(0.0002)$ & $(0.0002)$ \\
Years Since Migration3/1000 & 0.1075 & 0.1091 & 0.1112 & 0.1104 \\
& $(0.0300)$ & $(0.0303)$ & $(0.0303)$ & $(0.0307)$ \\
Arrival Cohort Pre-1950 & 0.0588 & -0.4240 & -0.3593 & -0.3661 \\
& $(0.1510)$ & $(0.1541)$ & $(0.1548)$ & $(0.1559)$ \\
Arrival Cohort 1950-59 & -0.0070 & -0.3631 & -0.3157 & -0.3227 \\
& $(0.1032)$ & $(0.1056)$ & $(0.1061)$ & $(0.1069)$ \\
Arrival Cohort 1960-64 & -0.0135 & -0.2744 & -0.2382 & -0.2438 \\
& $(0.0805)$ & $(0.0824)$ & $(0.0827)$ & $(0.0834)$ \\
Arrival Cohort 1965-69 & -0.0335 & -0.2237 & -0.1967 & -0.2002 \\
& $(0.0656)$ & $(0.0671)$ & $(0.0674)$ & $(0.0680)$ \\
Arrival Cohort 1970-74 & 0.0193 & -0.0990 & -0.0789 & -0.0819 \\
& $(0.0515)$ & $(0.0526)$ & $(0.0528)$ & $(0.0534)$ \\
Arrival Cohort 1975-79 & 0.0149 & -0.0579 & -0.0444 & -0.0482 \\
& $(0.0379)$ & $(0.0387)$ & $(0.0389)$ & $(0.0393)$ \\
Arrival Cohort 1980-84 & 0.0458 & 0.0086 & 0.0153 & 0.0132 \\
& $(0.0304)$ & $(0.0311)$ & $(0.0311)$ & $(0.0318)$ \\
Proportion of Immigrants from & & & 0.6650 & 0.6655 \\
Same Country in SMSA & & & $(0.1167)$ & $(0.1188)$ \\
Ratio of S-E earnings to W/S earnings & & & & 0.0182 \\
by SMSA and Ethnicity of Natives & & & & $(0.0089)$ \\
Ratio of S-E earnings to W/S earnings & & & & 0.0483 \\
by SMSA and National Origin Group & & & & \\
& & & & \\
Sample Size & -4342779 & 1342779 & 1342779 & 1342779 \\
Log Likelihood & -454043 & -453178 & -453161 & -441567 \\
\hline
\end{tabular}

Note. Standard errors are presented in parentheses. All models include interactions between education and period effect, education interacted with period effect and immigrant status, in addition to dummies for regions, SMSA residency, disability and for being married. 
Table 8

OLS Weekly Wage Models for Males Aged 18-64, Based on 1980 and 1990 Public Use Samples of the U.S. Census.

\begin{tabular}{|c|c|c|c|c|}
\hline \multirow[t]{2}{*}{ Variable } & \multicolumn{2}{|c|}{ Self-Employed } & \multicolumn{2}{|c|}{ Wage/Salary } \\
\hline & Model 1 & Model 2 & Model 1 & Model 2 \\
\hline \multirow[t]{2}{*}{ Constant } & 3.0797 & -0.7753 & 2.7430 & 3.0173 \\
\hline & $(0.0968)$ & (1.0676) & $(0.0168)$ & (0.0224) \\
\hline \multirow[t]{2}{*}{ Immigrant } & 0.9177 & 1.9554 & 1.1660 & 0.7977 \\
\hline & $(0.3617)$ & $(0.4612)$ & $(0.0652)$ & (0.0682) \\
\hline \multirow[t]{2}{*}{ Mexico } & -0.1325 & -0.3713 & -0.0697 & -0.0082 \\
\hline & (0.0602) & $(0.0893)$ & $(0.0154)$ & $(0.0158)$ \\
\hline \multirow[t]{2}{*}{ South and Central America } & -0.0965 & -0.1962 & -0.0562 & -0.0252 \\
\hline & $(0.0606)$ & $(0.0665)$ & $(0.0157)$ & $(0.0158)$ \\
\hline \multirow[t]{2}{*}{ South East Asia } & -0.0265 & -0.2554 & -0.0799 & -0.0134 \\
\hline & $(0.0637)$ & $(0.0897)$ & $(0.0159)$ & $(0.0163)$ \\
\hline \multirow[t]{2}{*}{ North East Asia } & -0.0938 & 0.0455 & 0.0387 & -0.0160 \\
\hline & (0.0584) & (0.0699) & $(0.0161)$ & $(0.0164)$ \\
\hline \multirow[t]{2}{*}{ India/Pakistan } & 0.1448 & 0.1070 & 0.0870 & 0.0979 \\
\hline & $(0.0652)$ & $(0.0660)$ & $(0.0174)$ & $(0.0175)$ \\
\hline \multirow[t]{2}{*}{ Middle East } & 0.0616 & 0.3027 & 0.0924 & -0.0112 \\
\hline & $(0.0602)$ & $(0.0897)$ & $(0.0177)$ & $(0.0185)$ \\
\hline \multirow[t]{2}{*}{ Europe/Canada/Australia/New Zealand } & 0.0549 & 0.1124 & 0.1633 & 0.1406 \\
\hline & $(0.0564)$ & $(0.0586)$ & $(0.0152)$ & $(0.0152)$ \\
\hline \multirow[t]{2}{*}{ Caribbean } & -0.1593 & -0.3583 & -0.1043 & -0.0483 \\
\hline & $(0.0677)$ & $(0.0871)$ & $(0.0165)$ & $(0.0168)$ \\
\hline \multirow[t]{2}{*}{ Cuba } & -0.0963 & -0.0168 & -0.0229 & -0.0490 \\
\hline & $(0.0624)$ & $(0.0661)$ & $(0.0171)$ & $(0.0172)$ \\
\hline \multirow[t]{2}{*}{ Period Effect 1980} & 0.3884 & 0.3502 & 0.4061 & 0.4160 \\
\hline & $(0.0182)$ & $(0.0210)$ & $(0.0048)$ & $(0.0049)$ \\
\hline \multirow[t]{2}{*}{ Age } & 0.0676 & 0.2075 & 0.1136 & 0.0968 \\
\hline & $(0.0075)$ & $(0.0393)$ & $(0.0014)$ & $(0.0017)$ \\
\hline \multirow[t]{2}{*}{ Age2 } & -0.0007 & -0.0035 & -0.0017 & -0.0015 \\
\hline & $(0.0002)$ & $(0.0008)$ & $(0.00004)$ & $(0.00004)$ \\
\hline \multirow[t]{2}{*}{ Age3/1000 } & -0.0072 & 0.1894 & 0.0758 & 0.0606 \\
\hline & $(0.0147)$ & $(0.0562)$ & $(0.0031)$ & $(0.0032)$ \\
\hline \multirow[t]{2}{*}{ Years of Schooling } & 0.0983 & 0.1229 & 0.0796 & 0.0714 \\
\hline & $(0.0010)$ & $(0.0068)$ & $(0.0003)$ & $(0.0005)$ \\
\hline \multirow[t]{2}{*}{ Years of Schooling*Immigrant } & -0.0363 & -0.0553 & -0.0350 & -0.0290 \\
\hline & $(0.0023)$ & $(0.0057)$ & $(0.0006)$ & (0.0007) \\
\hline
\end{tabular}


Table 8 (Continued)

\begin{tabular}{|c|c|c|c|c|}
\hline Age*Immigrant & $\begin{array}{l}-0.0422 \\
(0.0275)\end{array}$ & $\begin{array}{l}-0.1138 \\
(0.0338)\end{array}$ & $\begin{array}{l}-0.0589 \\
(0.0053)\end{array}$ & $\begin{array}{l}-0.0338 \\
(0.0054)\end{array}$ \\
\hline Age2*Immigrant & $\begin{array}{l}0.0009 \\
(0.0007)\end{array}$ & $\begin{array}{l}0.0028 \\
(0.0009)\end{array}$ & $\begin{array}{l}0.0011 \\
(0.0001)\end{array}$ & $\begin{array}{l}0.0005 \\
(0.0001)\end{array}$ \\
\hline Age3/1000*Immigrant & $\begin{array}{l}-0.0625 \\
(0.0537)\end{array}$ & $\begin{array}{l}-0.2226 \\
(0.0695)\end{array}$ & $\begin{array}{l}-0.0757 \\
(0.0116)\end{array}$ & $\begin{array}{l}-0.0187 \\
(0.0120)\end{array}$ \\
\hline Speaks Little or No English & $\begin{array}{l}-0.1484 \\
(0.0237)\end{array}$ & $\begin{array}{l}-0.2064 \\
(0.0286)\end{array}$ & $\begin{array}{l}-0.1488 \\
(0.0052)\end{array}$ & $\begin{array}{l}-0.1374 \\
(0.0052)\end{array}$ \\
\hline Years Since Migration & $\begin{array}{l}0.0428 \\
(0.0072)\end{array}$ & $\begin{array}{l}0.0718 \\
(0.0108)\end{array}$ & $\begin{array}{l}0.0289 \\
(0.0016)\end{array}$ & $\begin{array}{l}0.0222 \\
(0.0016)\end{array}$ \\
\hline Years Since Migration2 & $\begin{array}{c}0.0000 \\
(0.0003)\end{array}$ & $\begin{array}{l}-0.0008 \\
(0.0004)\end{array}$ & $\begin{array}{l}0.0003 \\
(0.0001)\end{array}$ & $\begin{array}{l}0.0004 \\
(0.0001)\end{array}$ \\
\hline Years Since Migration3/1000 & $\begin{array}{l}0.0076 \\
(0.0410)\end{array}$ & $\begin{array}{l}0.0775 \\
(0.0453)\end{array}$ & $\begin{array}{l}-0.0367 \\
(0.0115)\end{array}$ & $\begin{array}{l}-0.0481 \\
(0.0115)\end{array}$ \\
\hline Arrival Cohort Pre-1950 & $\begin{array}{l}-1.6573 \\
(0.2173)\end{array}$ & $\begin{array}{l}-1.9049 \\
(0.2278)\end{array}$ & $\begin{array}{l}-1.3338 \\
(0.0515)\end{array}$ & $\begin{array}{l}-1.2617 \\
(0.0517)\end{array}$ \\
\hline Arrival Cohort 1950-59 & $\begin{array}{l}-1.0811 \\
(0.1504)\end{array}$ & $\begin{array}{l}-1.2954 \\
(0.1616)\end{array}$ & $\begin{array}{l}-0.8453 \\
(0.0345)\end{array}$ & $\begin{array}{l}-0.7818 \\
(0.0346)\end{array}$ \\
\hline Arrival Cohort 1960-64 & $\begin{array}{l}-0.7429 \\
(0.1184)\end{array}$ & $\begin{array}{l}-0.9044 \\
(0.1265)\end{array}$ & $\begin{array}{l}-0.5768 \\
(0.0265)\end{array}$ & $\begin{array}{l}-0.5308 \\
(0.0266)\end{array}$ \\
\hline Arrival Cohort 1965-69 & $\begin{array}{l}-0.5662 \\
(0.0973)\end{array}$ & $\begin{array}{l}-0.6973 \\
(0.1038)\end{array}$ & $\begin{array}{l}-0.4374 \\
(0.0212)\end{array}$ & $\begin{array}{l}-0.3996 \\
(0.0213)\end{array}$ \\
\hline Arrival Cohort 1970-74 & $\begin{array}{l}-0.3888 \\
(0.0770)\end{array}$ & $\begin{array}{l}-0.4442 \\
(0.0785)\end{array}$ & $\begin{array}{l}-0.3103 \\
(0.0164)\end{array}$ & $\begin{array}{l}-0.2956 \\
(0.0164)\end{array}$ \\
\hline Arrival Cohort 1975-79 & $\begin{array}{l}-0.2657 \\
(0.0575)\end{array}$ & $\begin{array}{l}-0.2977 \\
(0.0582)\end{array}$ & $\begin{array}{l}-0.1912 \\
(0.0117)\end{array}$ & $\begin{array}{l}-0.1836 \\
(0.0117)\end{array}$ \\
\hline Arrival Cohort 1980-84 & $\begin{array}{l}-0.1637 \\
(0.0465)\end{array}$ & $\begin{array}{l}-0.1538 \\
(0.0466)\end{array}$ & $\begin{array}{l}-0.1107 \\
(0.0096)\end{array}$ & $\begin{array}{l}-0.1117 \\
(0.0096)\end{array}$ \\
\hline Correction Term & & $\begin{array}{l}0.7830 \\
(0.2160)\end{array}$ & & $\begin{array}{l}0.6799 \\
(0.0368)\end{array}$ \\
\hline $\begin{array}{l}\text { Sample Size } \\
\text { R-square }\end{array}$ & $\begin{array}{r}152243 \\
0.1841\end{array}$ & $\begin{array}{r}152243 \\
0.1843\end{array}$ & $\begin{array}{r}1190536 \\
0.3088\end{array}$ & $\begin{array}{r}1190536 \\
0.3090\end{array}$ \\
\hline
\end{tabular}

Note. Standard errors are presented in parentheses. Model 2 standard errors are White corrected standard errors since the Heckman two-step procedure introduces heteroskedasticity of the disturbance term. All models include interactions between education and period effect, education interacted with period effect and immigrant status, in addition to dummies for regions, SMSA residency, disability and for being married. 
Figure 1

\section{Predicted Age-Earnings Profiles, No Control for Self Selection}

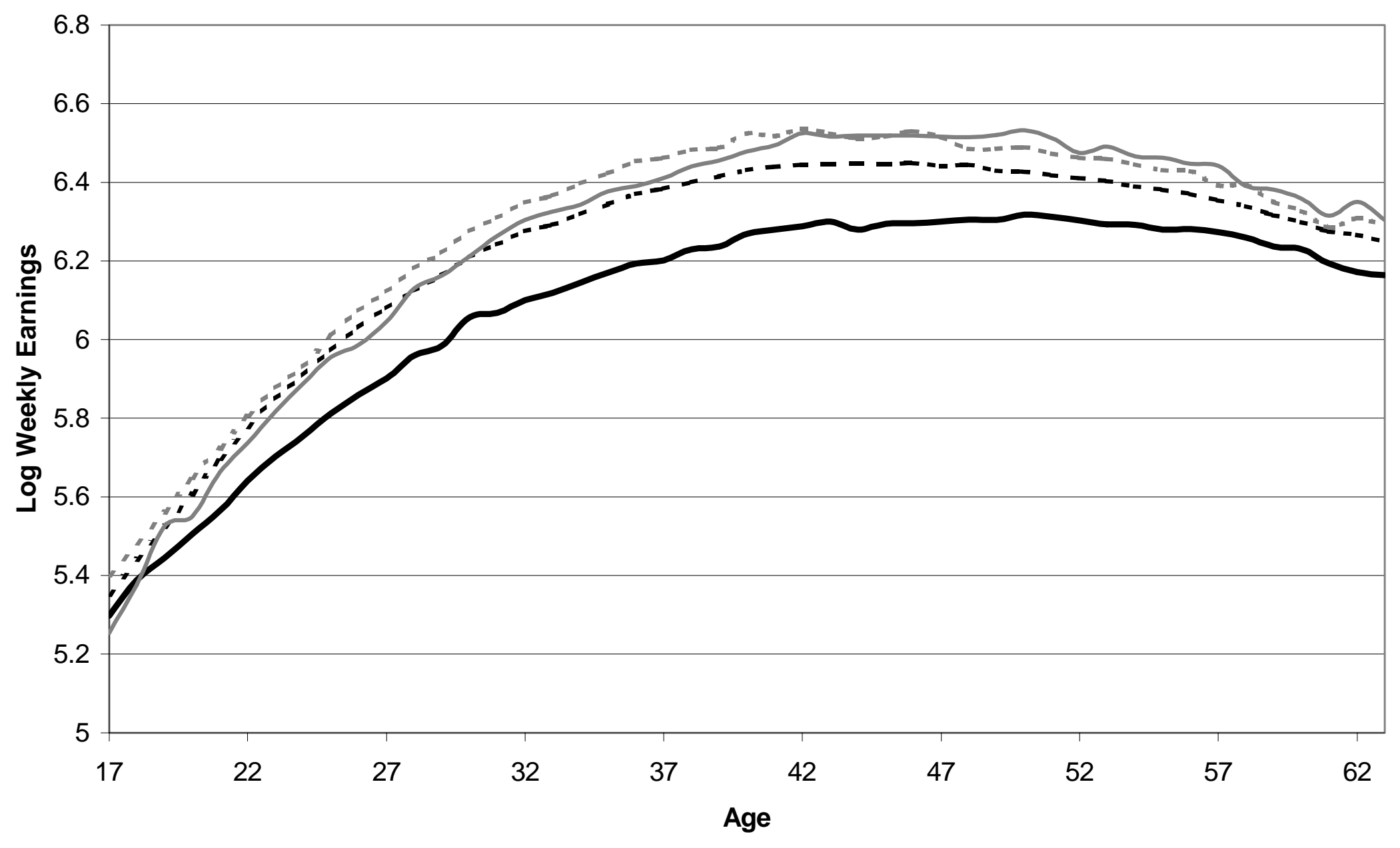

- - - Wage/Salary Natives —Wage/Salary Immigrants - - - Self-Employed Natives — Self-Employed Immigrants 
Figure 2

\section{Predicted Age-Earnings Profiles with Self Selection Correction}

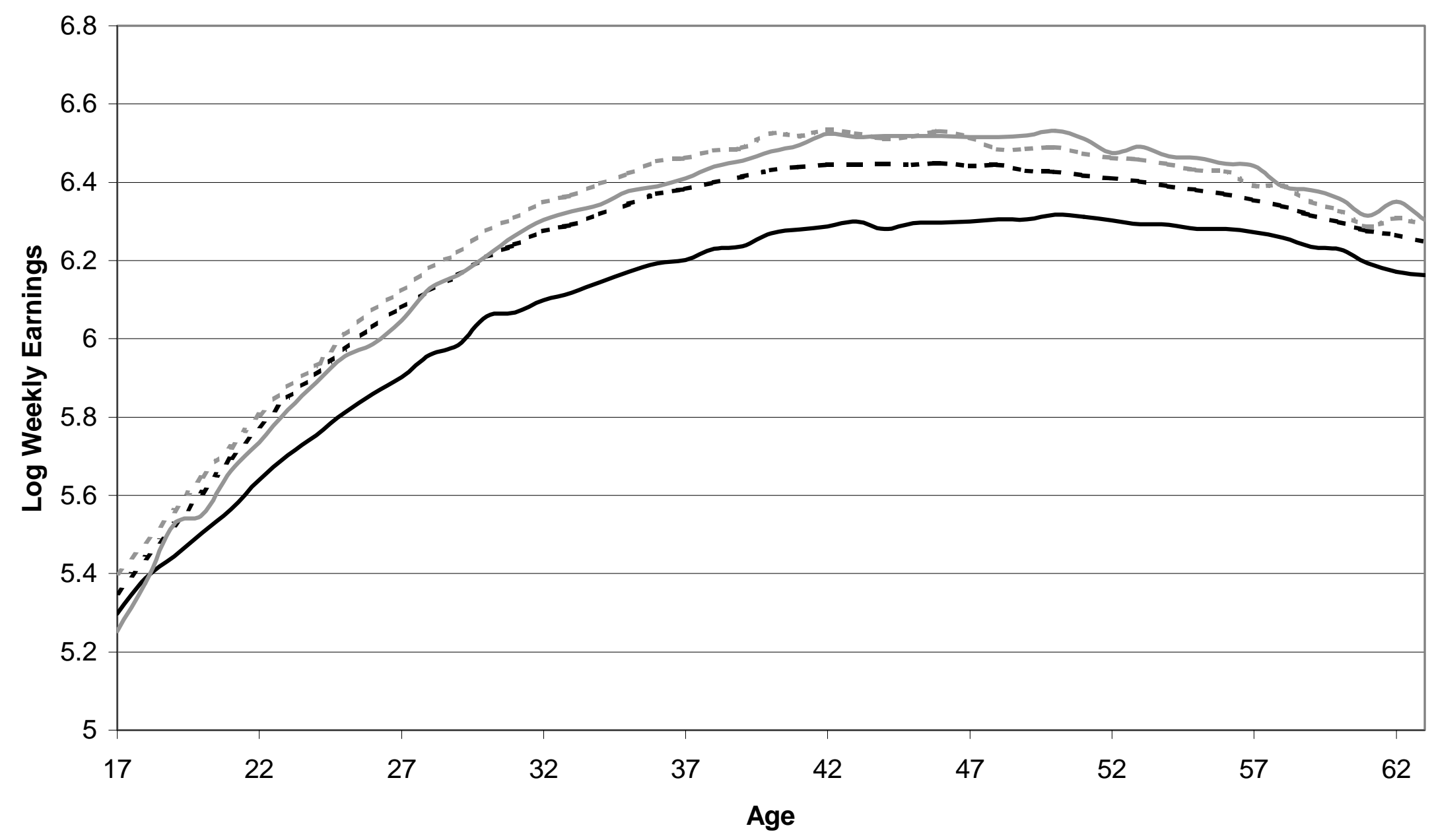


Figure 3

Predicted Log Weekly Earnings Gap, Immigrants-Natives

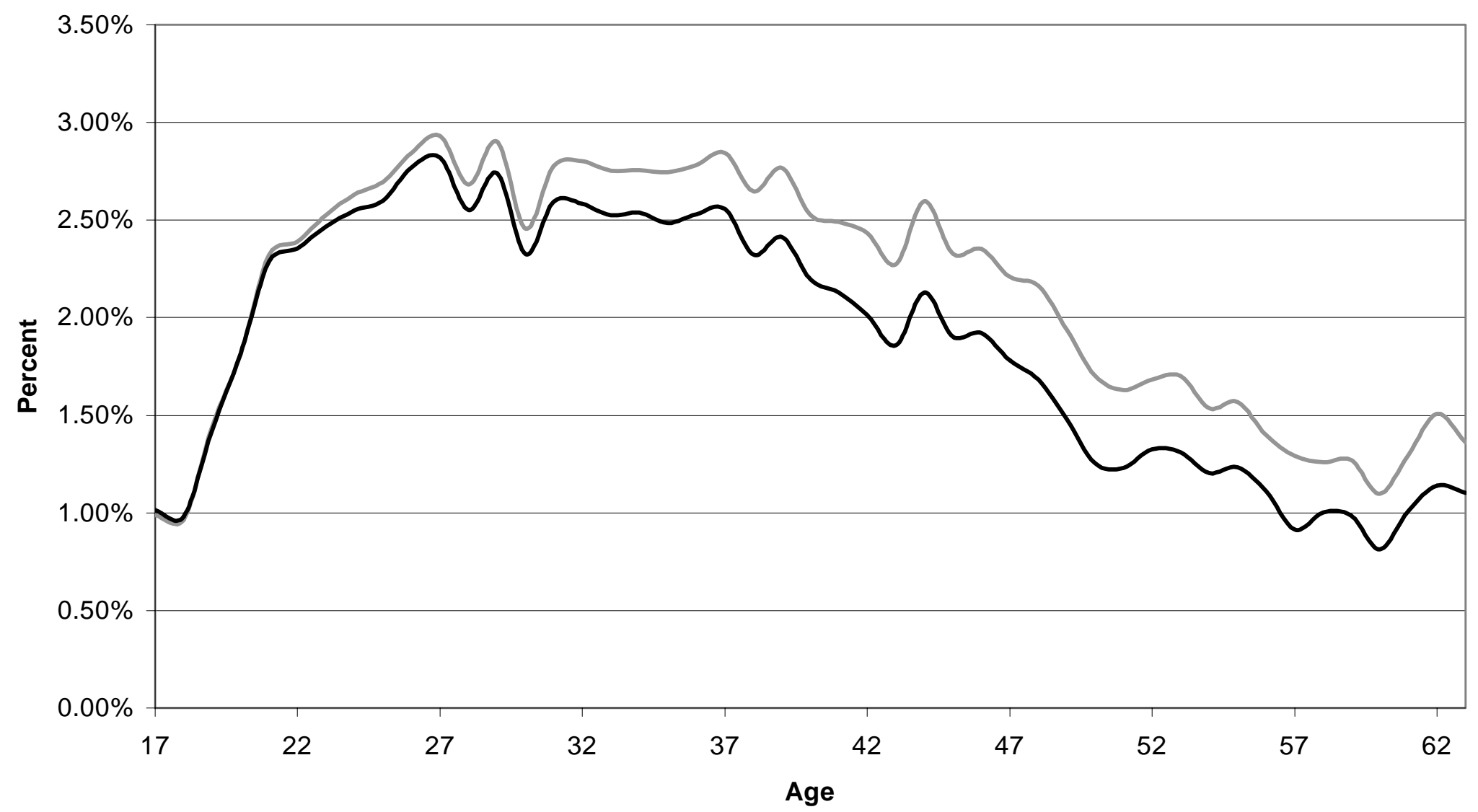

—Without Self-Employed —With Self-Employed 
Figure 4

\section{Self-Employment Rates by Age}

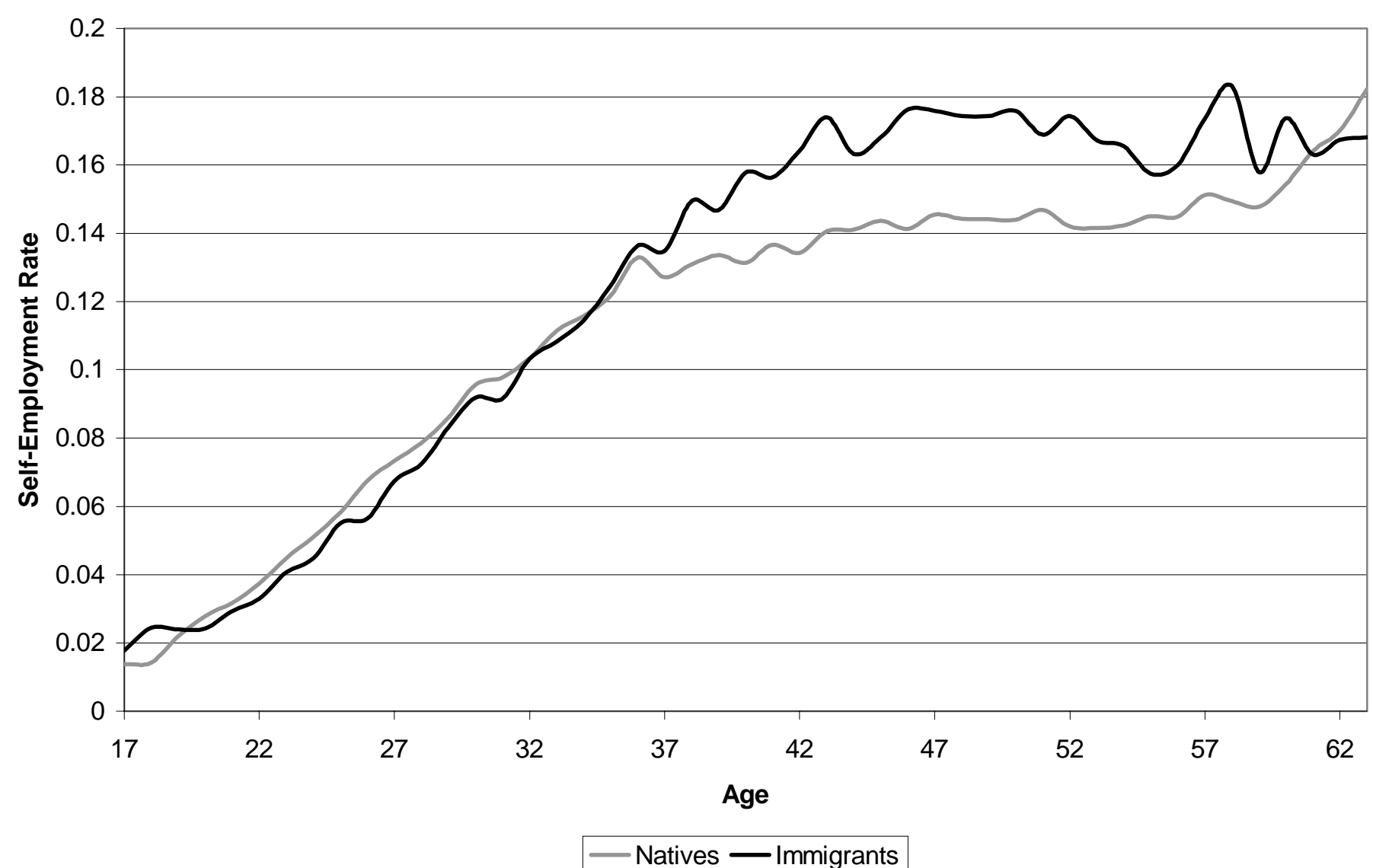


Figure 5

\section{Predicted Age-Wage/Salary Earnings Profiles with Self Selection Correction}

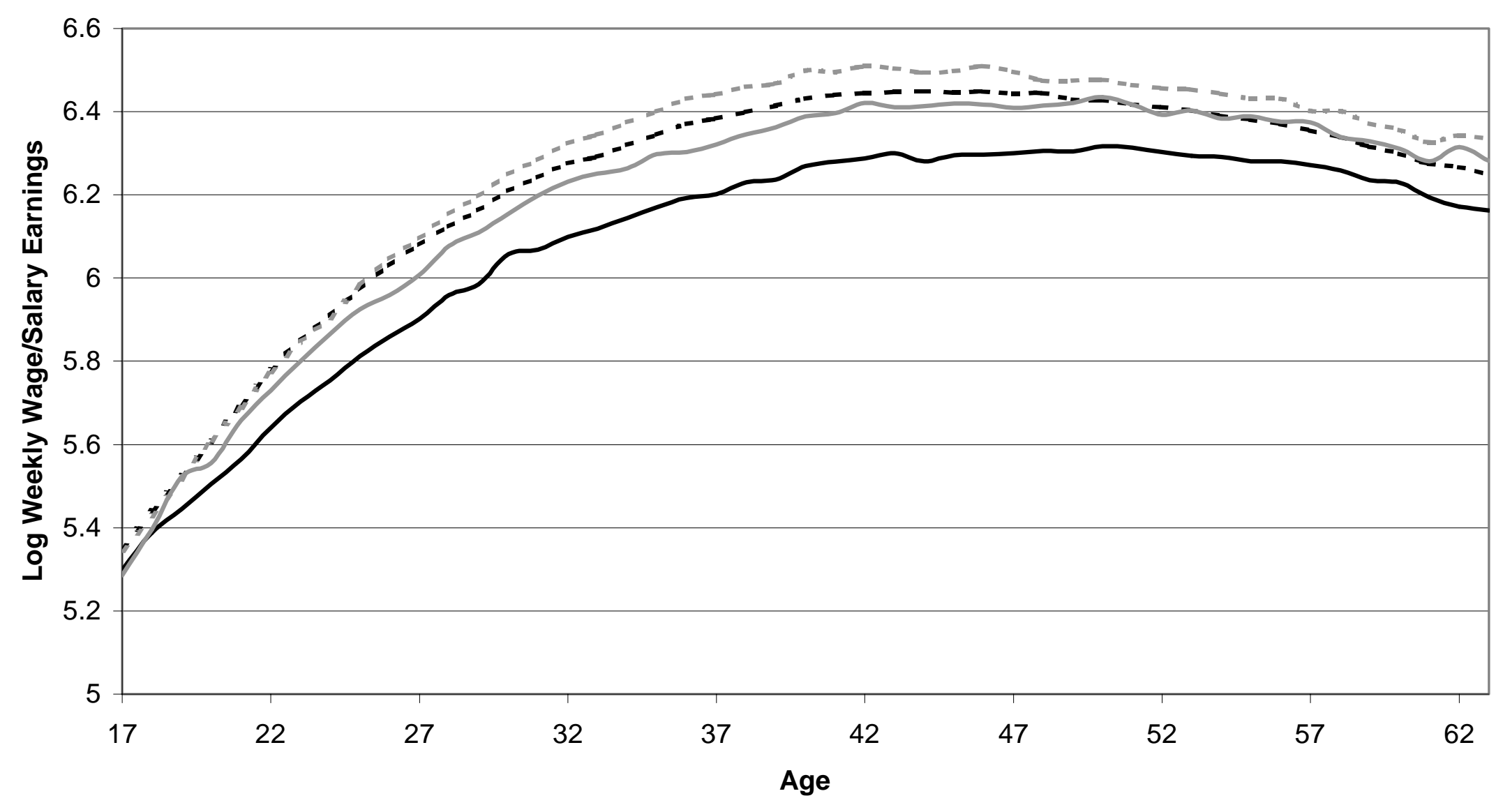

- - - Wage/Salary Natives —Wage/Salary Immigrants - " - Self-Employed Natives — Self-Employed Immigrants 
Figure 6

\section{Predicted Age-Earnings Profiles by Post 1965 Arrival Cohorts and 1965 and Before Arrival Cohorts}

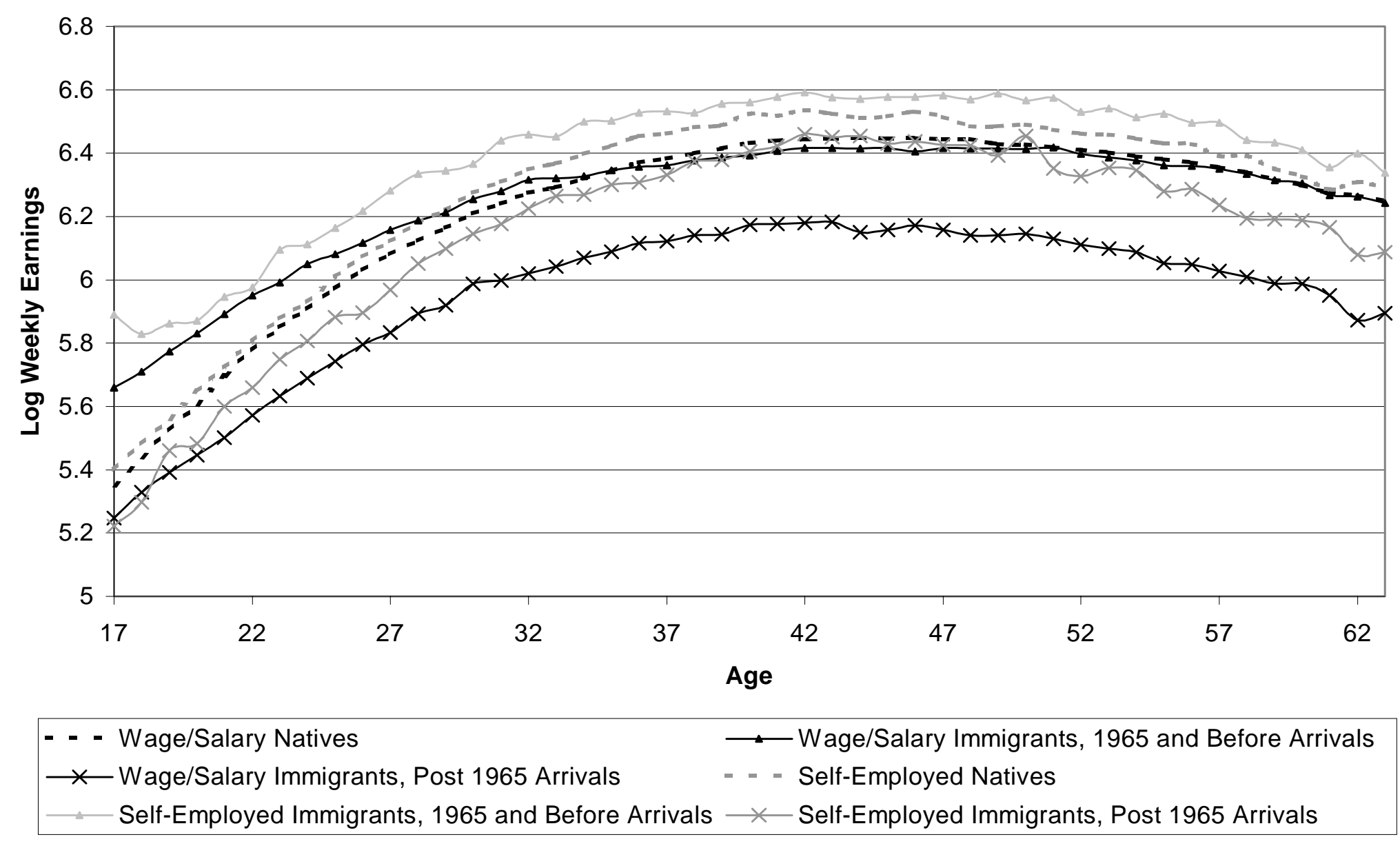


Figure 7

Predicted Relative Weekly Earnings, Natives/Immigrants, by Arrival Cohorts and Age Groups.

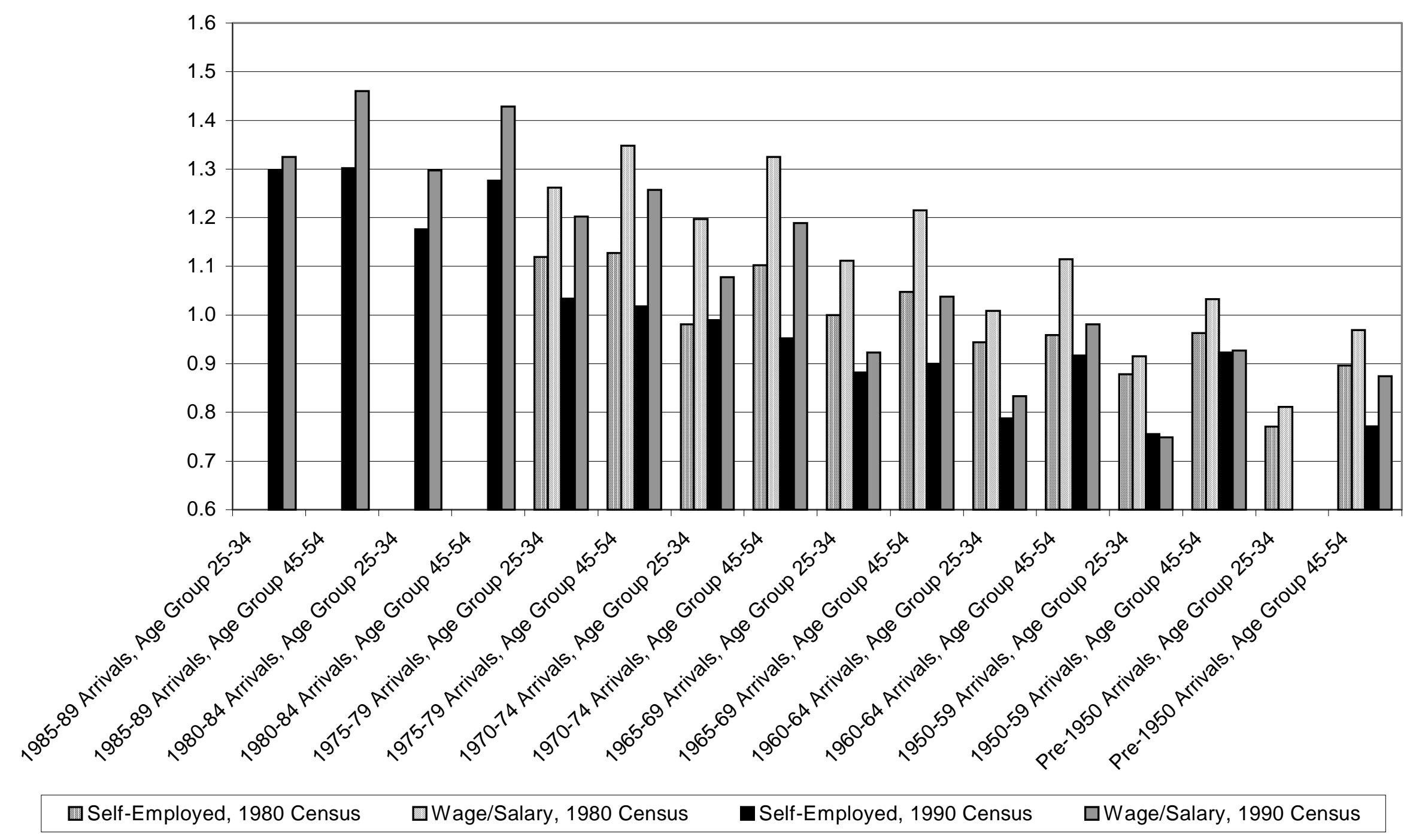


Table A1.

Definition of National Origin Groups.

\section{Mexico:}

Mexico

South and Central America:

Argentina, Bolivia, Brazil, Chile, Colombia, Ecuador, Falkland Islands, French Guyana, Guyana, Paraguay, Peru, Suriname, Uruguay, Venezuela, Belize, Costa Rica, El

Salvador, Guatemala, Honduras, Nicaragua, Panama.

South East Asia:

Bangladesh, Brunei, Burma, Cambodia, Indonesia, Laos, Macau, Malaysia, Philippines, Thailand, Vietnam.

North East Asia:

China, Hong Kong, Japan, North Korea, Singapore, South Korea, Taiwan.

\section{India/Pakistan:}

Bangladesh, Bhutan, India, Nepal, Pakistan, Sri Lanka.

Middle East/Egypt:

Bahrain, Cyprus, Iran, Iraq, Israel, Jordan, Kuwait, Lebanon, Oman, Qatar, Saudi Arabia, Syria, Turkey, United Arab Emirates, Yemen, Egypt.

\section{Europe, Canada, Australia, New Zealand:}

Albania, Andorra, Austria, Belgium, Bulgaria, Czechoslovakia, Denmark, Faeroe Islands, Finland, France, Germany, Gibraltar, Greece, Hungary, Iceland, Ireland, Italy, Liechtenstein, Luxembourg, Malta, Monaco, Netherlands, Norway, Poland, Portugal, Romania, San Marino, Spain, Sweden, Switzerland, United Kingdom, Vatican, Yugoslavia, Soviet Union, Canada, Australia, New Zealand.

\section{Caribbean:}

Anguilla, Antigua and Barbuda, Aruba, Bahamas, Barbados, British Virgin Islands, Cayman Islands, Dominica, Dominican Republic, Grenada, Guadeloupe, Haiti, Jamaica, Martinique, Montserrat, Netherlands Antilles, St. Barthelemy, St.Kitts-Nevis, St. Lucia, St. Vincent and the Grenadines, Trinidad and Tobago, Turks and Caicos Islands.

Cuba:

Cuba

\section{Africa:}

Algeria, Angola, Benin, Botswana, British Indian Ocean Territory, Burkina Faso, Burundi, Cameroon, Cape Verde, Central African Republic, Chad, Comoros, Congo, Djibouti, Equatorial Guinea, Ethiopia, Gabon, Gambia, Ghana, Glorioso Islands, Guinea, Guinea-Bissau, Ivory Coast, Juan de Nova Island, Kenya, Lesotho, Liberia, Libya, Madagascar, Malawi, Mali, Mauritania, Mayotte, Morocco, Mozambique, Namibia, Niger, Nigeria, Reunion, Rwanda, Sao Tome and Principe, Senegal, Mauritius, Seychelles, Sierra Leone, Somalia, South Africa, St. Helena, Sudan, Swaziland, Tanzania, Togo, Tromelin Island, Tunisia, Uganda, Western Sahara, Zaire, Zambia, Zimbabwe. 
Table A2

Ethnic Composition of National Origin Groups, Percent of Group Population.

\begin{tabular}{|c|c|c|c|c|c|c|c|c|c|c|}
\hline \multirow[b]{2}{*}{ Group } & \multicolumn{5}{|c|}{1980} & \multicolumn{5}{|c|}{1990} \\
\hline & White & Black & Asian & Hispanic & Other & White & Black & Asian & Hispanic & Other \\
\hline Natives & 86.3 & 8.9 & 0.6 & 3.6 & 0.6 & 86.7 & 7.9 & 0.7 & 4 & 0.7 \\
\hline All Immigrants & 44.5 & 5 & 15.3 & 34.6 & 0.6 & 28.3 & 5.6 & 21.2 & 44.7 & 0.2 \\
\hline \multicolumn{11}{|l|}{ National Origin Group: } \\
\hline Mexico & 0.8 & 0.2 & 0.1 & 98.6 & 0.3 & 0.4 & 0.3 & 0.2 & 98.8 & 0.3 \\
\hline Central/South America & 9.2 & 9.2 & 2 & 78.7 & 0.9 & 5.1 & 6.6 & 2.1 & 85.8 & 0.4 \\
\hline South East Asia & 5.4 & 0.2 & 92.4 & 0.6 & 1.4 & 1.9 & 0.1 & 97.8 & 0.2 & 0 \\
\hline North East Asia & 4.2 & 0.2 & 95.1 & 0.2 & 0.3 & 2 & 0.1 & 97.7 & 0.1 & 0.1 \\
\hline India, Pakistan, etc & 5.9 & 0.3 & 92.3 & 0.1 & 1.4 & 3.9 & 0.2 & 95.1 & 0.2 & 0.6 \\
\hline Middle East/Egypt & 95.2 & 0.2 & 1 & 1.1 & 2.5 & 97.6 & 0.2 & 1.5 & 0.6 & 0.1 \\
\hline Europe,CAN,AUS,NZ & 96.6 & 0.4 & 0.3 & 2.4 & 0.3 & 96.3 & 0.6 & 0.4 & 2.7 & 0 \\
\hline Africa & 48.5 & 36.7 & 9.5 & 2.3 & 3 & 32.8 & 55.9 & 10.1 & 1.2 & 0 \\
\hline Caribbean & 4 & 68.9 & 2.4 & 23.6 & 1.1 & 2.6 & 72.4 & 2.2 & 22.5 & 0.3 \\
\hline Cuba & 0.9 & 1.7 & 0.2 & 97.1 & 0.1 & 0.8 & 2.4 & 0.3 & 96.5 & 0 \\
\hline
\end{tabular}

